\title{
الربط بـ(آل) التعريفية في الجملة العربية
}

د. علي رمضان البيومي كلية دار العلوم/ جامعة الفيوم 


\section{المقدمة}

الحمد لله رب العالمين، والصلاة والسلام على أشرف المرسلين، وبعد؛ فالربط قرينة سياقية وتركيبة، وظيفتها التماسك بين عناصر النص وجعل بعضه آخذا

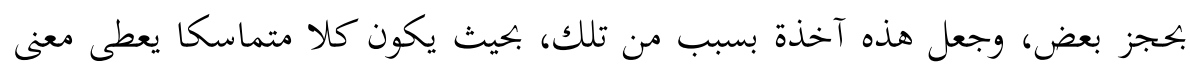

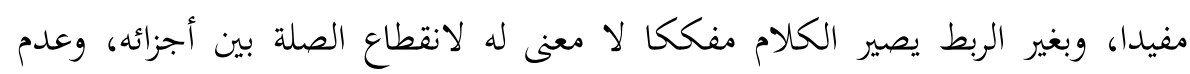

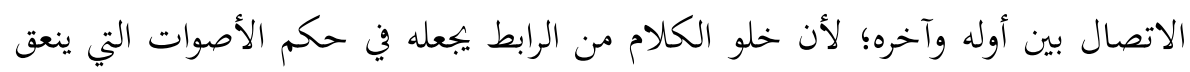

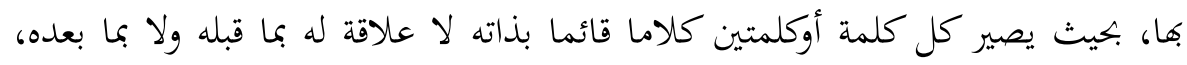

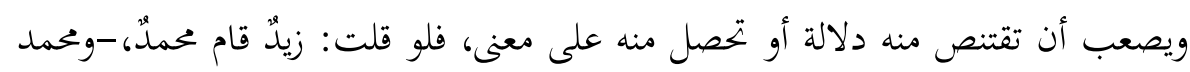

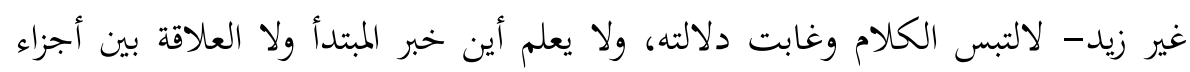

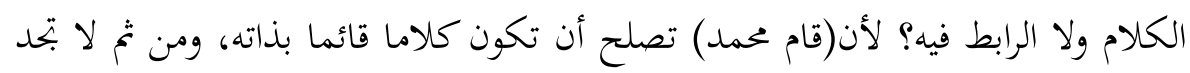
نصا عربيا أو جملة عربية صحيحة ذات معنى تخلو من وسيلة من وسائل الربط ، ووسائل

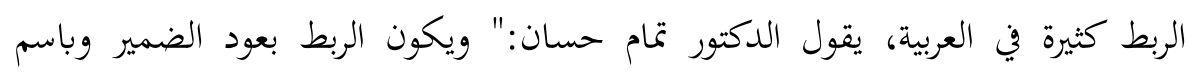
الإشارة وإعادة الذكر وإعادة المعنى ، أو بـ(أل)، أو بحرف الجوابي، أو أو الأدوات الداخلة

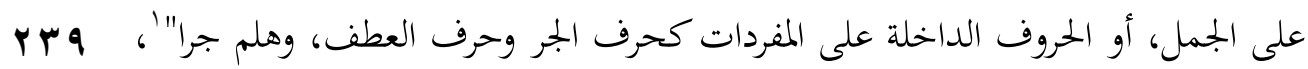

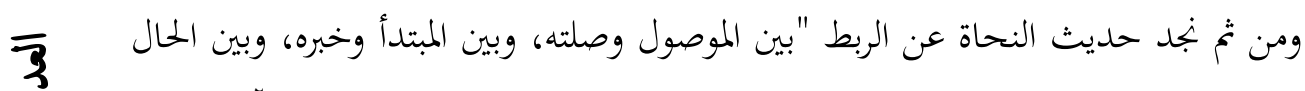

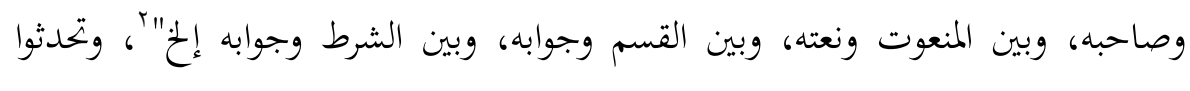

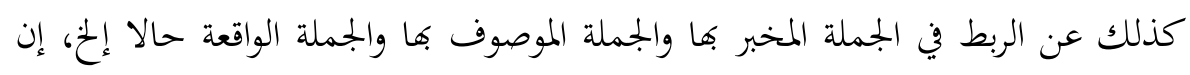
النحاة أدركوا قد قيمة الربط "باعتباره عنصرا أساسيا من عناصر التماسك بين أجزاء

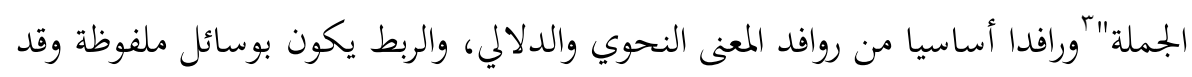
وقد يكون بوسائل معنوية ملحوظة، وهي التي يسميها الدكتور تمام بالقرائن اللفظية

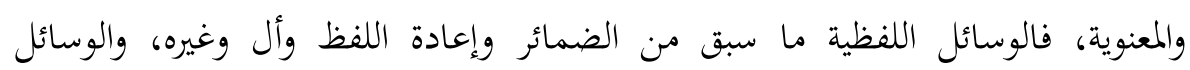

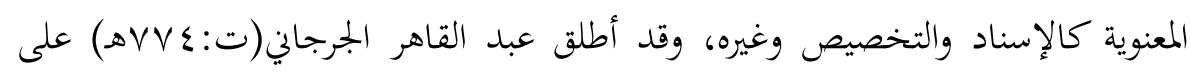

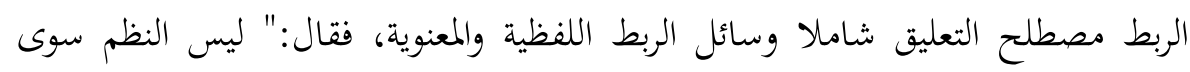
تعليق الكلم بعضها ببعض، وجعل بعضها بسبب من بعض، والكلم ثلاث، اسم وفعل

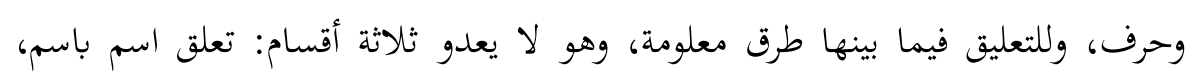


وتعلق اسم بفعل، وتعلق حرف بهما"؛، وعنوان هذا البحث يخص وسيلة لفظية من وسائل

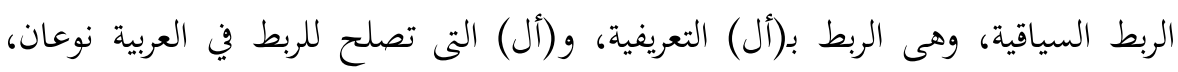

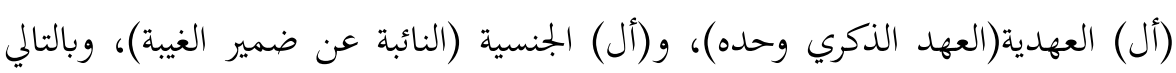
سيدور الحديث في هذا البحث عن النقاط التالية:

(1) الربط لغة واصطلاحا

(r) أنواع (أل) النعريفية في العربية

(r) (ب) الربط ب(أل) العهدية

( ) ( الربط ب(أل) الجنسية

(1) الربط لغة واصطلاحا:

لغة: ربط الشيء يربُطه ربطا: شده، والرباط والمرابطة: ملازمة ثغر العدو، وأصله: أن

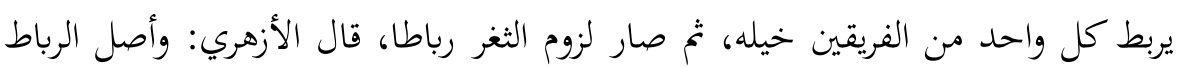

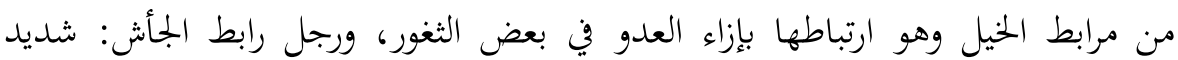

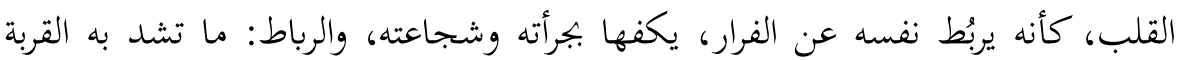
والدابة وغيرهما والجمع رُبُطْ .

اصطلاحا: الربط "قرينة لفظية على اتصال أحد المترابطين بالآخر "ا"، سواء أكان على لى

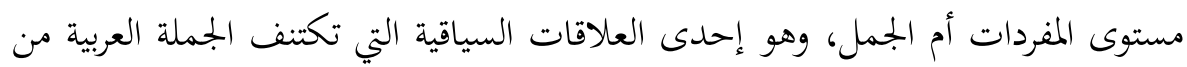

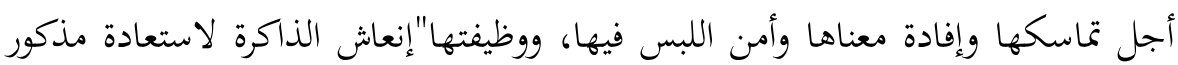

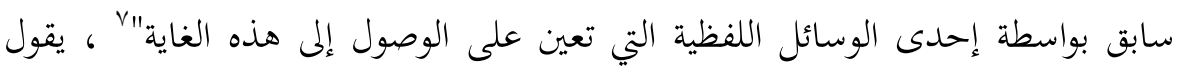

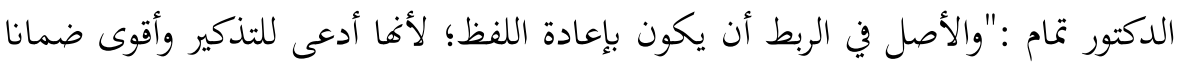

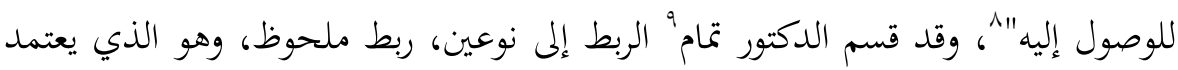
عليه السياق دون استخدام وسيلة لفظية بين المترابطين كالتخصيص والتفسير وغيرهما، ويعرفه الدكتور مصطفى حميدة بقوله:"علاقات سياقية نحوية تنشأ بين المعاني الوظيفية النحوية دون اللجوء إلى أداة لأن كل علاقة منها علاقة وثيقة أشبه بعلاقة الشيء بنفسه"'، وربط ملفوظ وهو الذي يعتمد عليه السياق باستخدام وسيلة لفظية بين المترابطين كالحروف والأدوات والضمائر وغيرهم، ويعرفه الدكتور مصطفى حميدة بقوله: 
"علاقة سياقية نحوية بين طرفين باستعمال أداة تدل على تلك العلاقة" "'، والأول يسمى قرينة معنوية والثاني يسمى قرينة لفظية، والذي نعنيه هنا هو الربط الملفوظ والمستخدم فيه (أل) كأداة تربط لاحق الجملة بأولها، وتقوم فيها مقام الضمير.

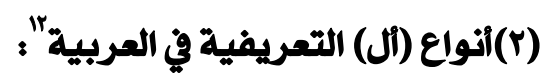

(أل): إحدى وسائل تعريف الاسم في العربية، بل هي أشهر وسائل التعريف، وهي

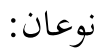

الأول: (أل) العهدية، والعهد ثلاثة أنواع، عهد ذكري، وعهد ذهني(علمي)، وعهد حضوري. (أل) التي للعهد الذكري: وهي التي عُهََ مدلول مصحوبها متقدما ومذكورا في اللفظ

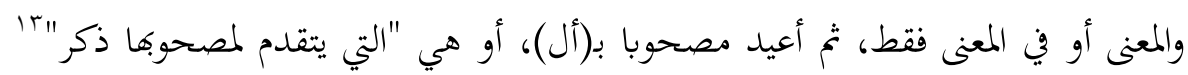

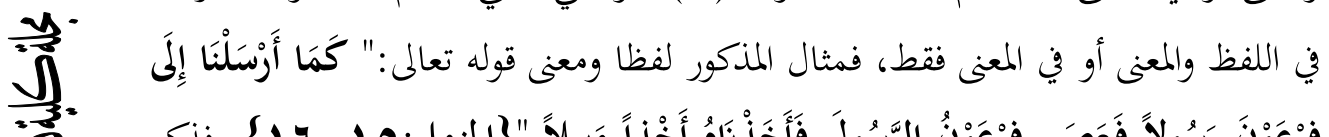

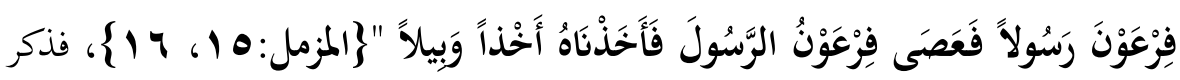

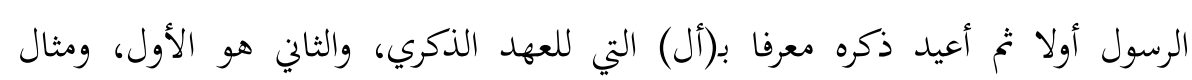

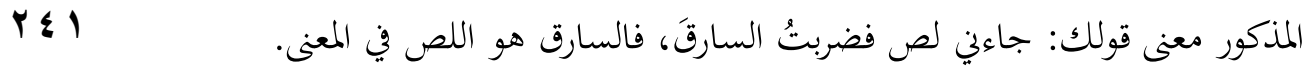

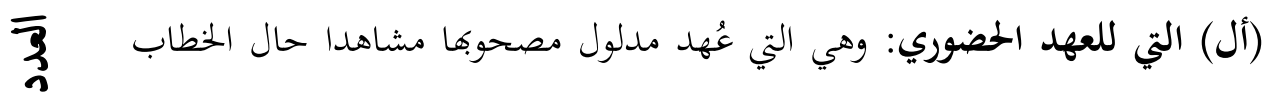

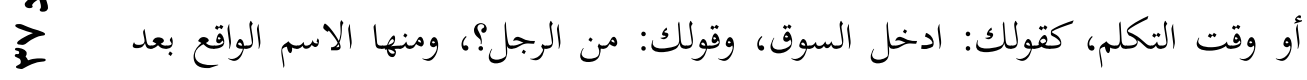

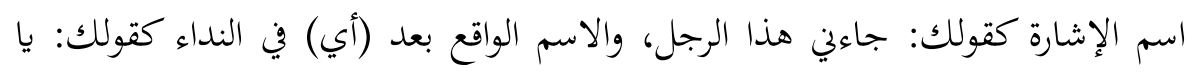

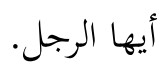

(أل) التي للعهد الذهني (العهد العلمي): وهي التي عهد مدلول مصحوبها في ذهن

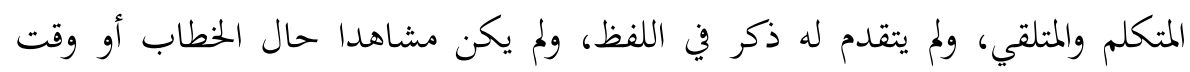

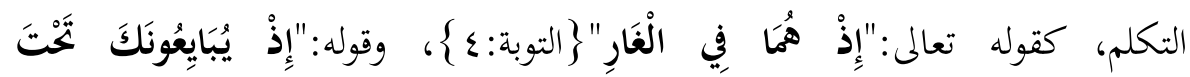

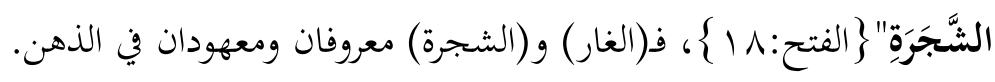
الثاني: (أل) الجنسية، وهي ثلاثة أنواع، لتعريف الماهية، ولاستغراق جميع أفراد الجنس حقيقة، ولا ستغراق جميع أفراد الجنس بجازا. 
(أل) الجنسية لتعريف الماهية أو لتعريف الحقيقة؛'، وهذه لا يصح أن يعاقبها (كل)

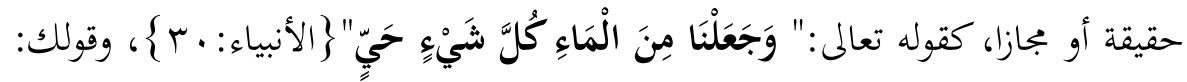

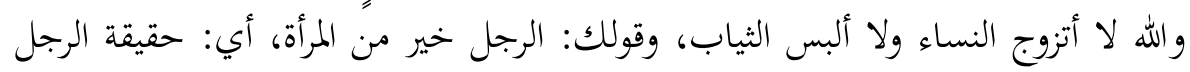

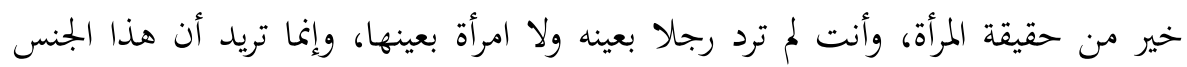

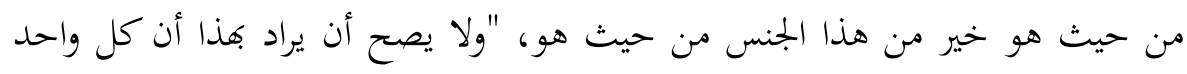

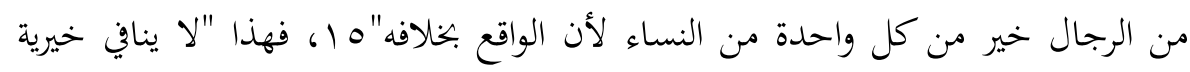

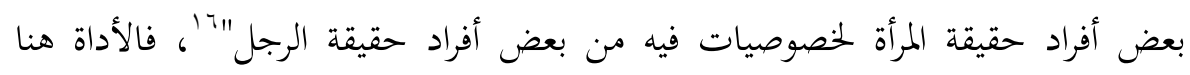

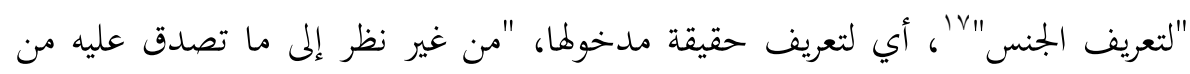

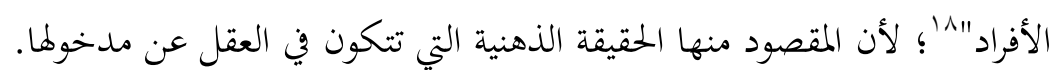

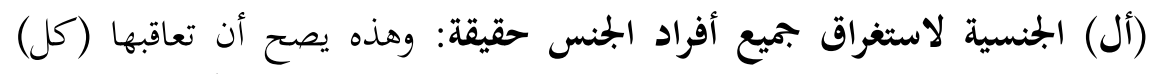

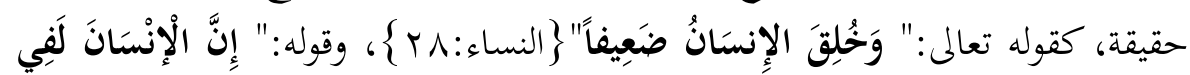

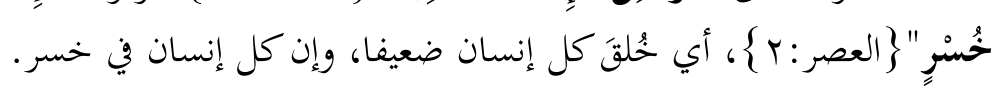

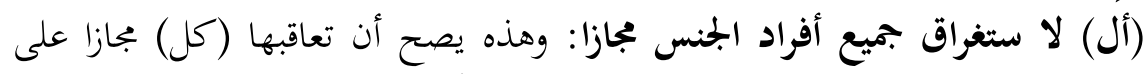

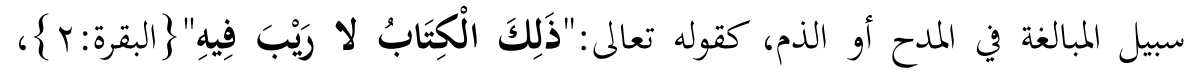

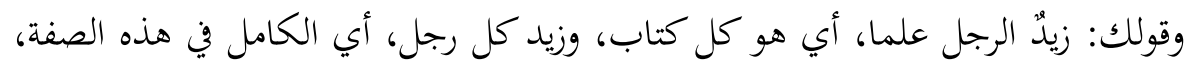

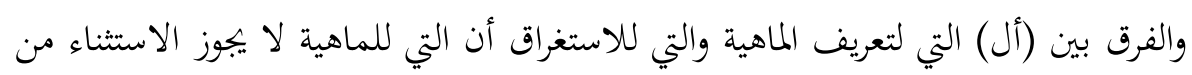

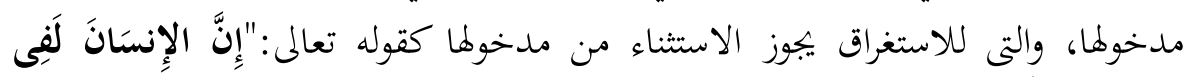

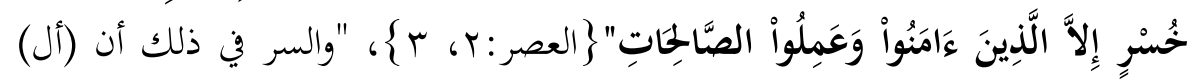

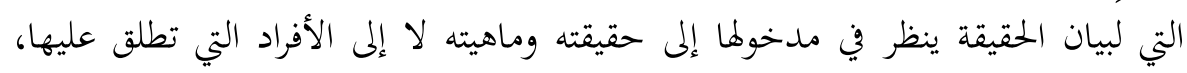

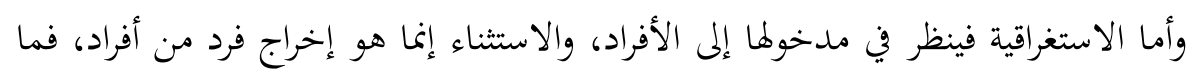

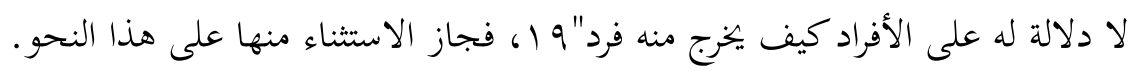

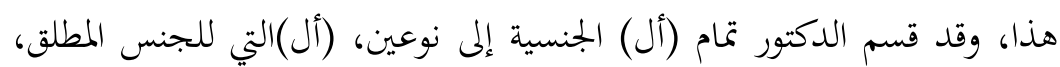

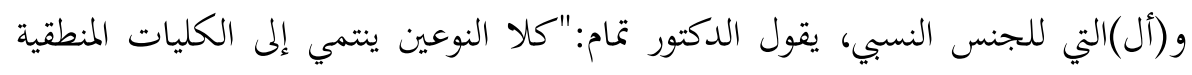

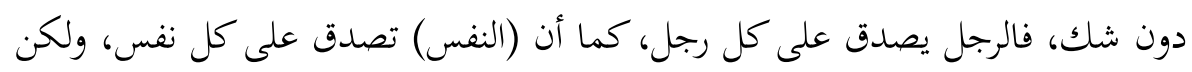

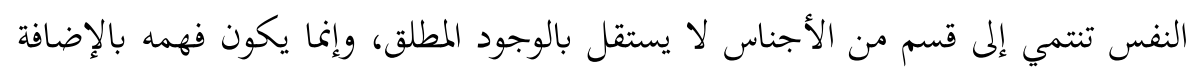

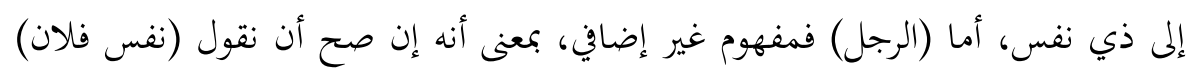

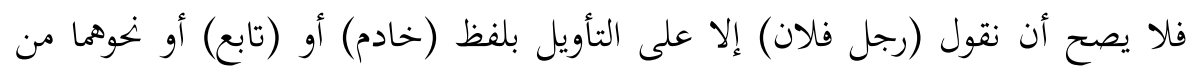

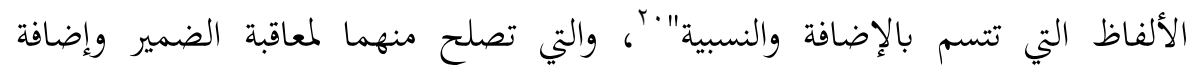

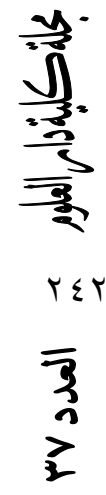


مدخولها للضمير (أل) التي للجنس النسبي، وقد عنى الدكتور تمام بالجنس المطلق ما أطلقه

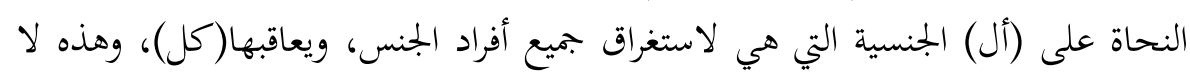

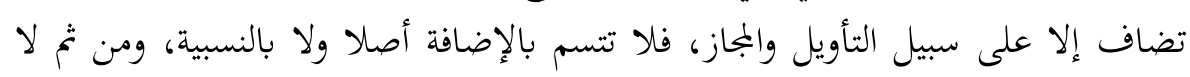

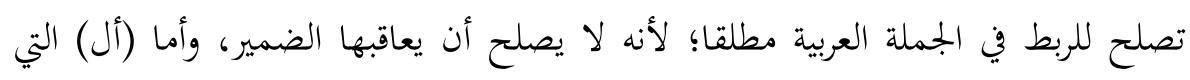

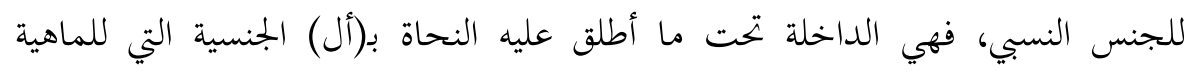

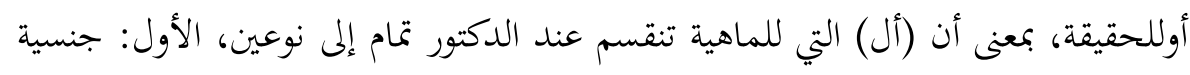

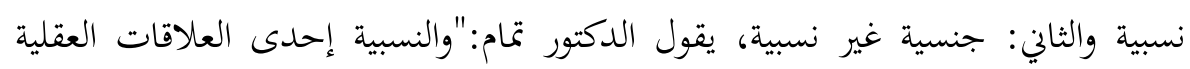

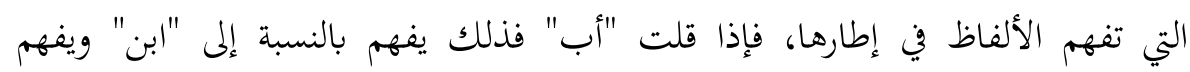

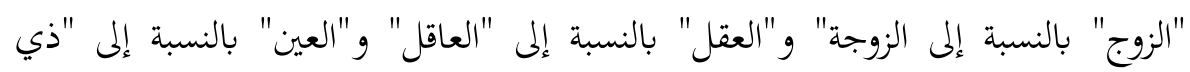

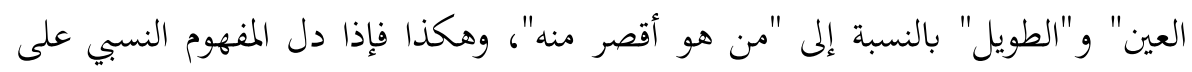

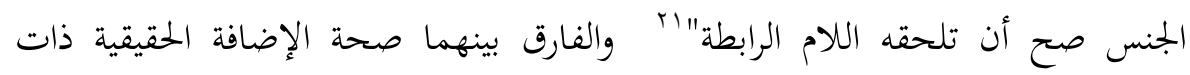

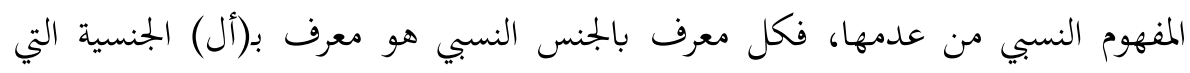

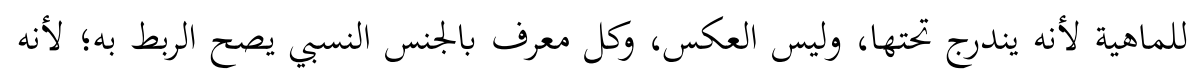

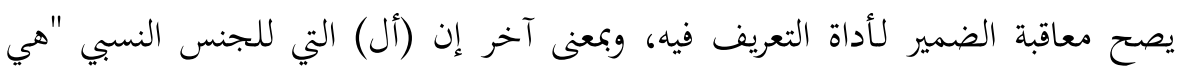

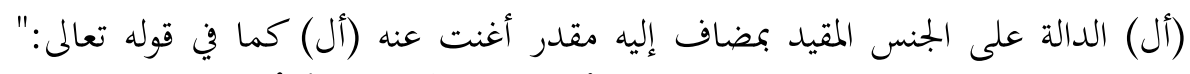

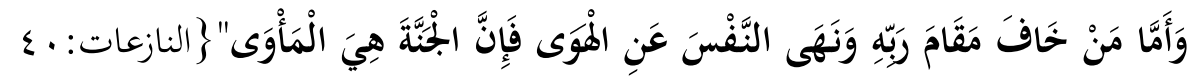
،

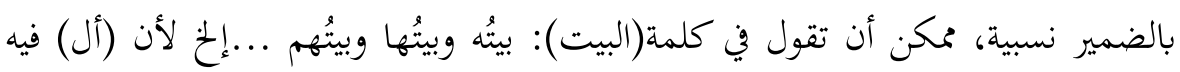

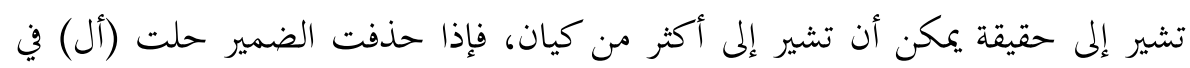

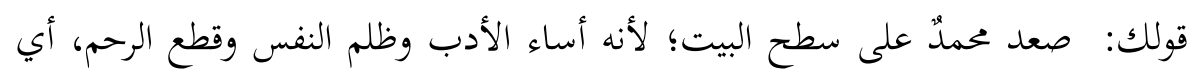

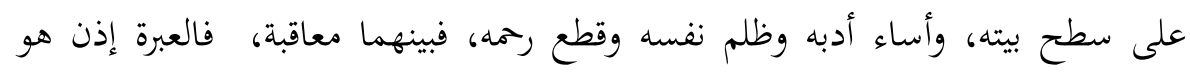

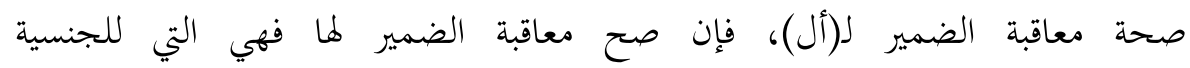

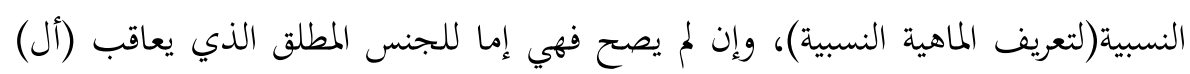

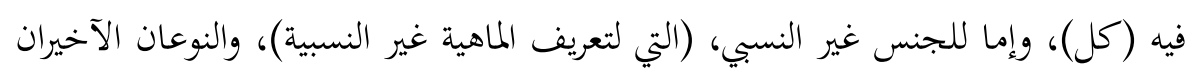

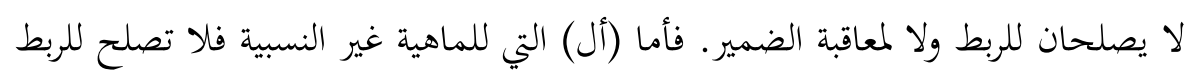

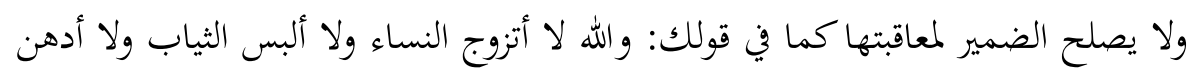

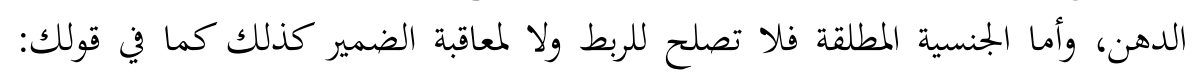

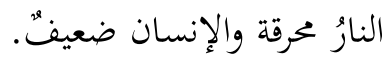


من كل مماسبق يتضح أن (أل) تربط إذا كانت للجنس النسبي أو للعهد الذكري،

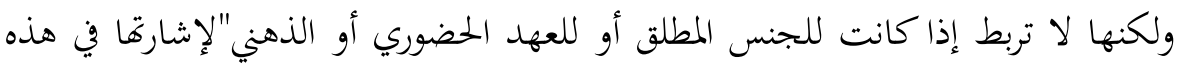

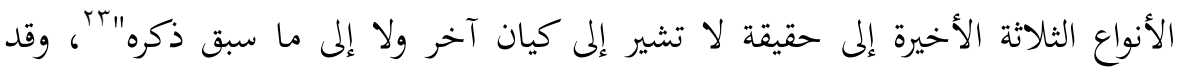

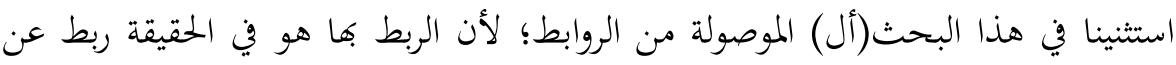

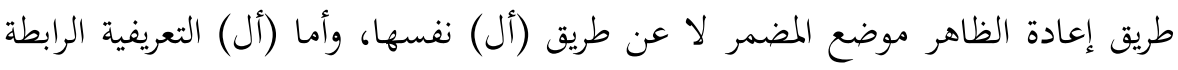

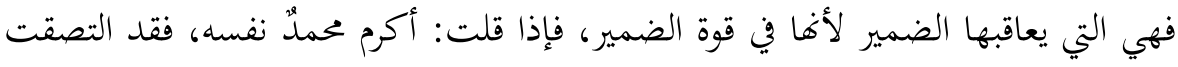

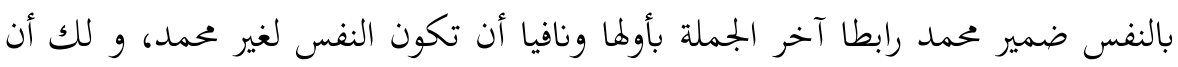

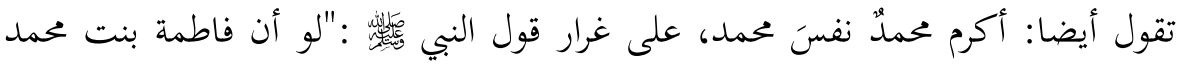

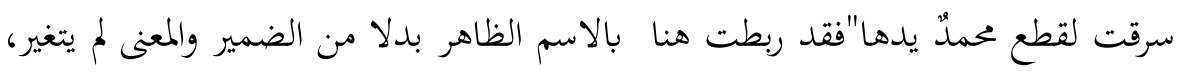

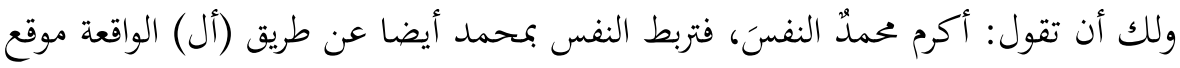

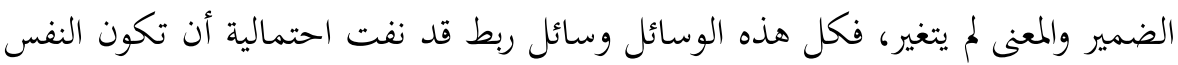

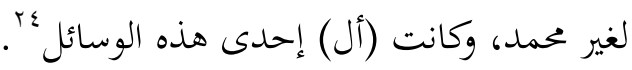

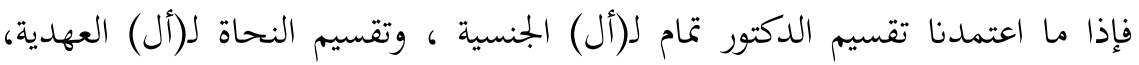

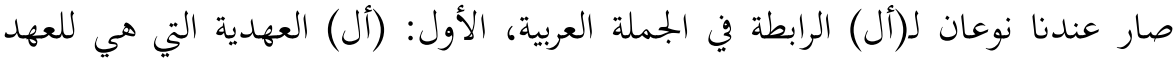

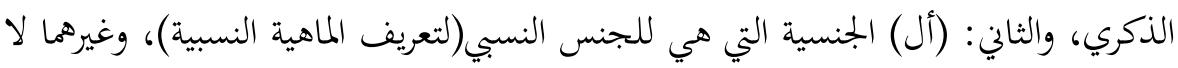
يربط مطلقا.

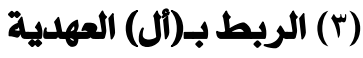

المراد بـ(أل) العهدية هنا - كما تقدم- التي للعهد الذكري، وهي التي عهد

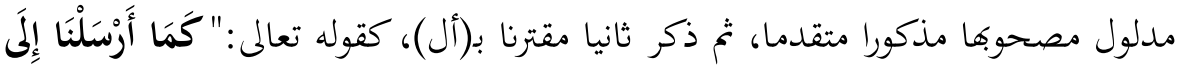

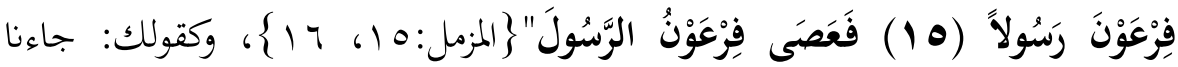
ضيفُ فأكرمنا الضيف، فقد ذكر (الرسول) و(الضيف) مرتين بلفظ واحد، الأولى منكرا،

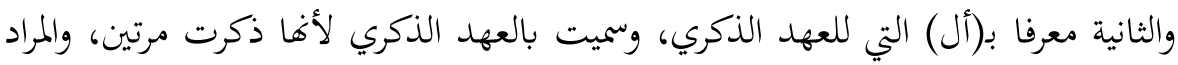

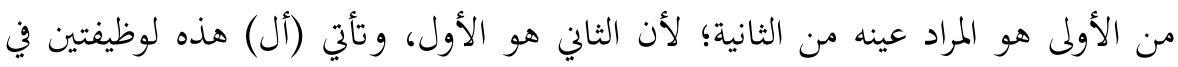
الجملة العربية:

الوظيفة الأولى : دفع اللبس والتوهم؛ لأنك لو قلت: جاءنا ضيفُ فأكرمنا ضيفا،

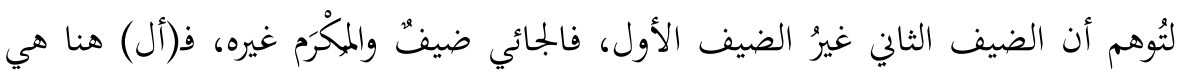

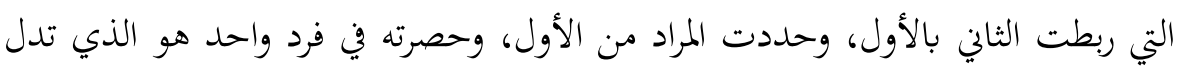


عليه النكرة الأولى، وكذلك لو قلت - في غير القرآن- كما أرسلنا إلى فرعون رسولا

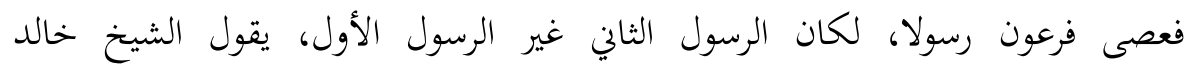

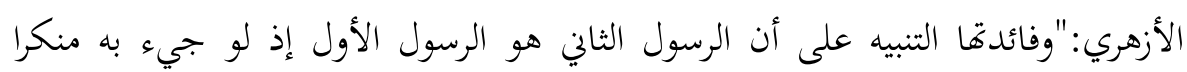

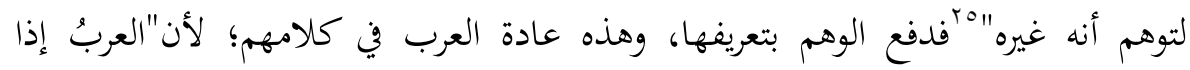

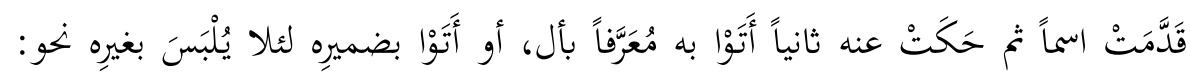

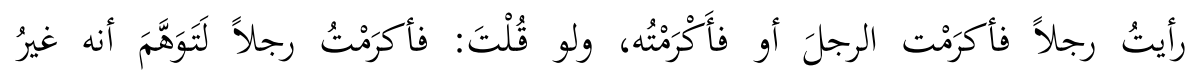

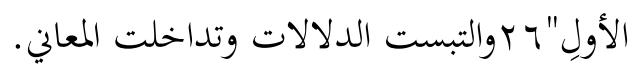

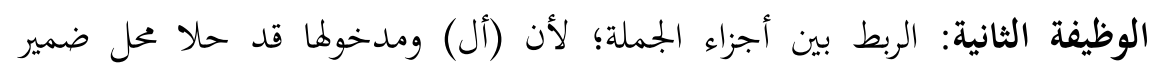

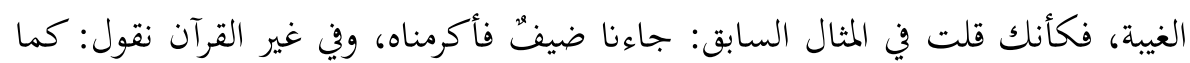

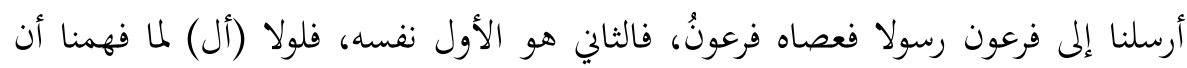

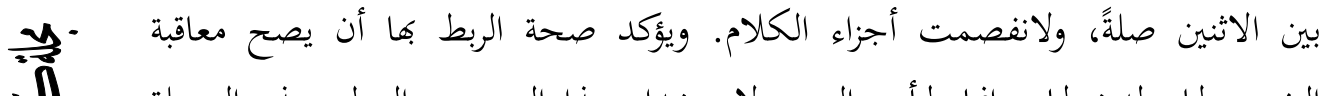

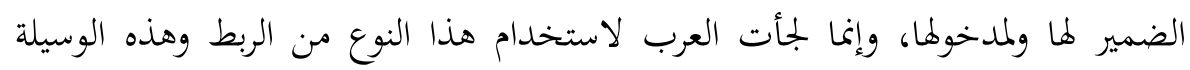

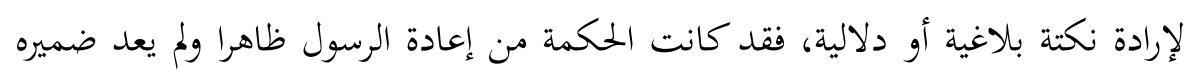

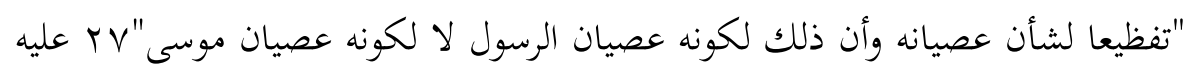

معنى ذلك أن (أل) التي للعهد الذكري تأتي للربط بين أجزاء الجملة العربية، شأها في

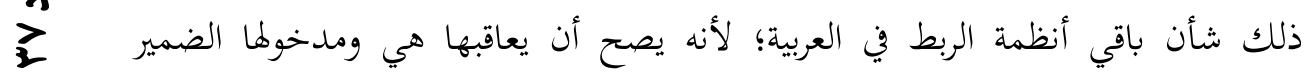

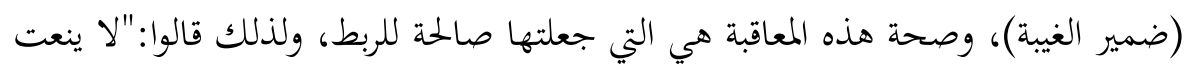

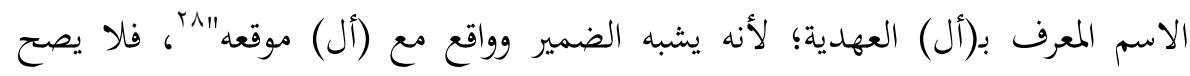

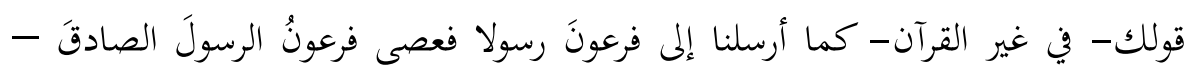

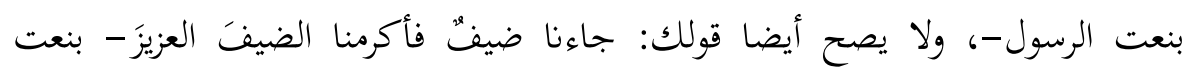
الضيف- ؛ لأن (أل) ومدخولها قد نابا عن الضمير، فيكون التقدير فيهما: فعصاه

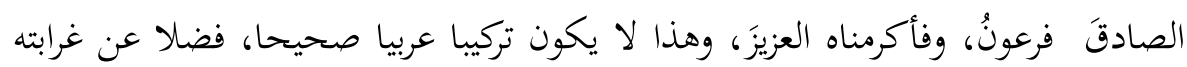

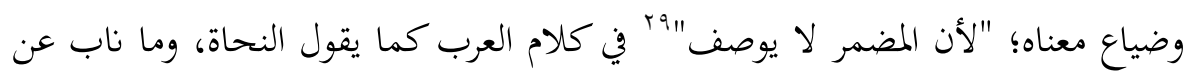

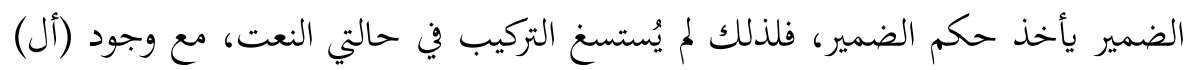
ومدخولها، أو مع وجود الضمير. 
وملا كان اللفظ الثاني (أل ومدخوها) نائبا عن الضمير، وكان الأول مرجعا لذلك الضمير، ساغ اعتبار الثاني معرفة. وملا كان اللفظ الثاني (أل ومدخوها) نائبا عن الضمير، وكان الأول مرجعا لذلك ألك أنكارك

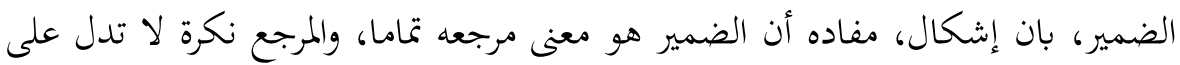
معين والضمير معرفة يدل على معين، فكيف وقع ذلك؟ والجواب"أن الضمير قد أوصلنا إلى شيء واحد مع أن هذا الشيء الواحد ينطبق على أفراد كثيرة... ولأن معناها مراد به وفيه

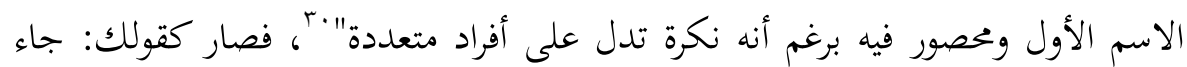

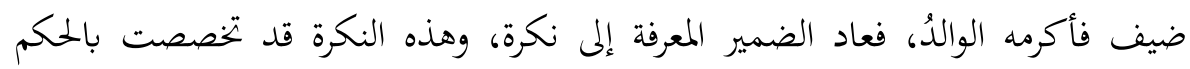
قبل، ويوضح هذا الشيخ عباس حسن عندما تحدث عن وظيفة (أل)، فقال: "وظيفتها الربط بين النكرتين ربطا معنويا، يجعل معنى الثانية فردا محدودا محصورا فيما دخلت عيل عليه

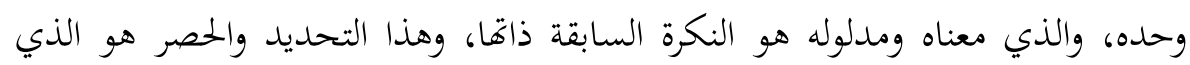
جعل الثانية معرفة؛ لأفما صارت معهودة عهدا ذكريا أدى إلى تعيين الغرض وتحديده بعد

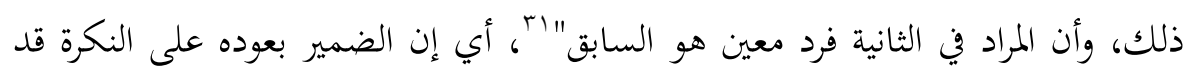

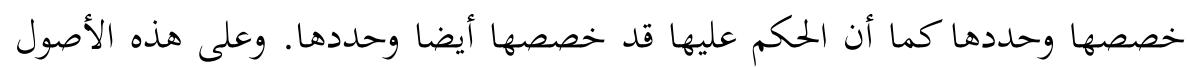

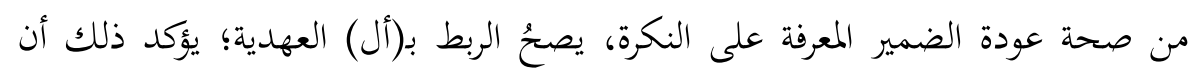

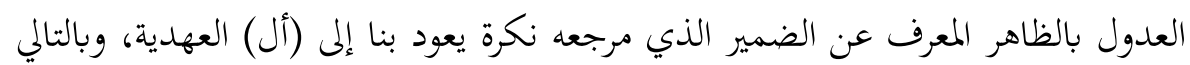

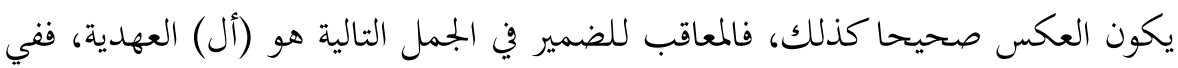

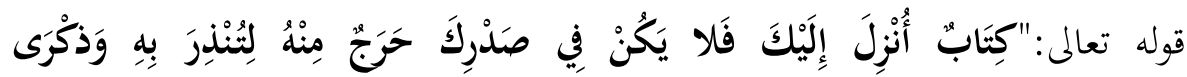

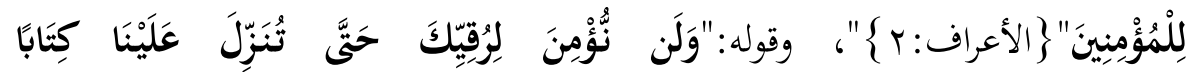

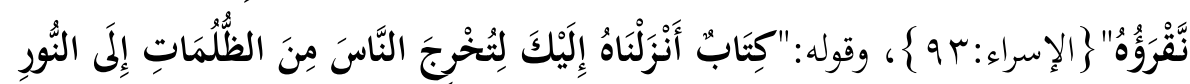

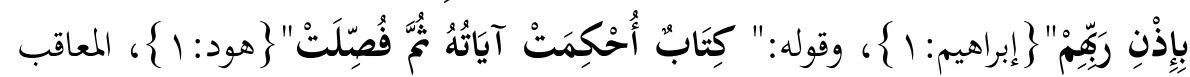
للضمير في الآيات السابقة هو (أل) العهدية، فتقول - في غير القرآن- فلا يكن في

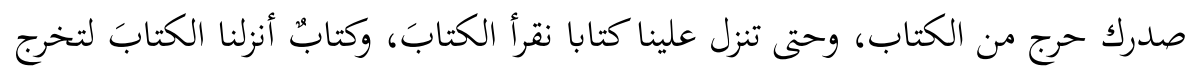

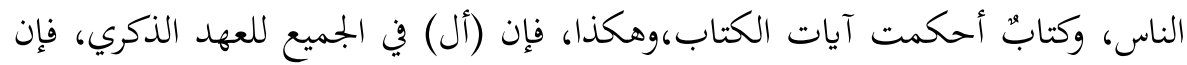
أردت العودة بالظاهر (أل ومدخولها) إلى المضمر صح المعنى ولم يتغير. 
نكرة + أل ومدخولها (النكرة مكررة لفظا أو معنى)= نكرة + ضمير الغيبة(عائد على النكرة المتقدمة) والعكس صحيح. ومما يؤكد الربط ب(أل) أيضا ذهاب جمهور النحاة إلى أن ضمير الغيبة العائد إلى النكرة معرفة ، وخاصة النكرة التي تخصصت بحكم نهو قولك: جاءلني رجلٌ فأكرمتُه، قالوا: إن في الضمير من التعيين والإشارة إلى المرجع ما ليس في المظهر النكرة، يقول الدماميني:"

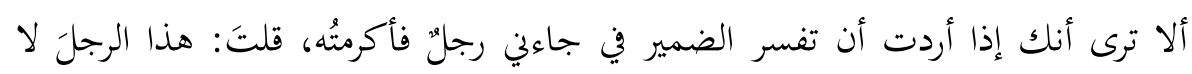

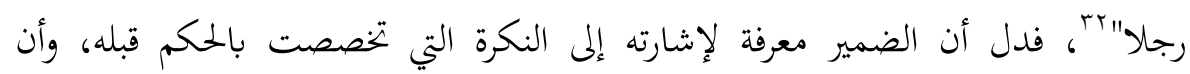

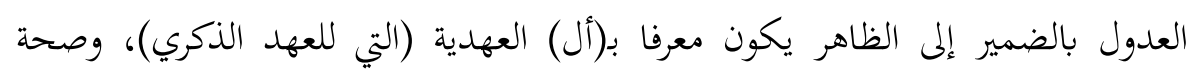

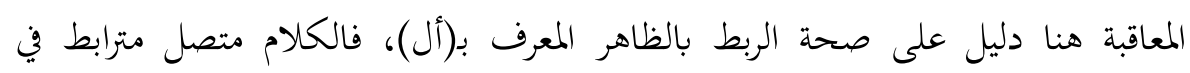

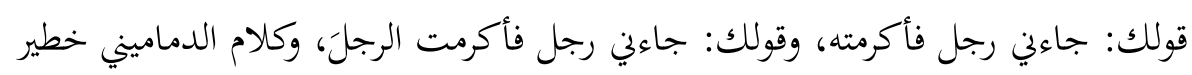

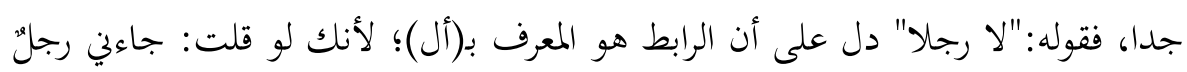

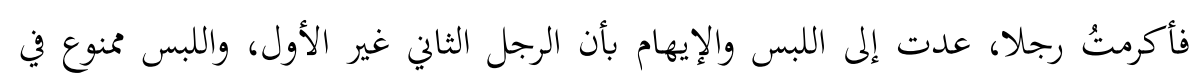

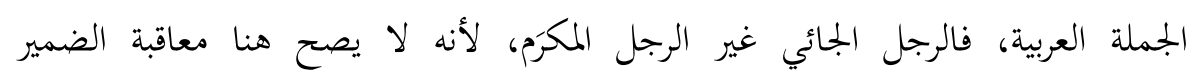
لكلمة(رجلا) في الجملة السابقة فبان الفصل بين الجملتين ولا ربط بينهما، كما أوضح

الدماميني من خلال كلامه أن الضمير معرفة فهو رابط قوي، وبديله (أل) العهدية (الرجل) لا النكرة (رجلا)؛ لأن النكرة لا تدل على مرجع ولا تشير إلى متقدم. يمكن الآن أن نتحدث عن بعض الأمثلة التي وردت فيها (أل) التي للعهد

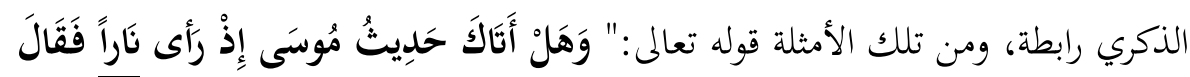

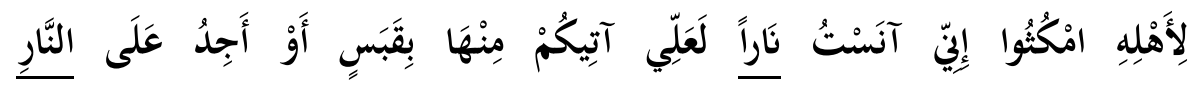

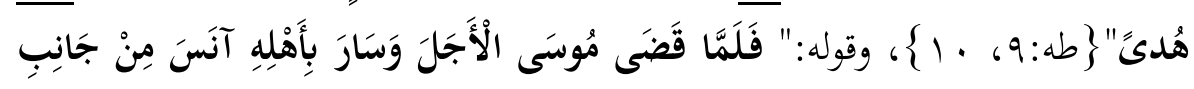

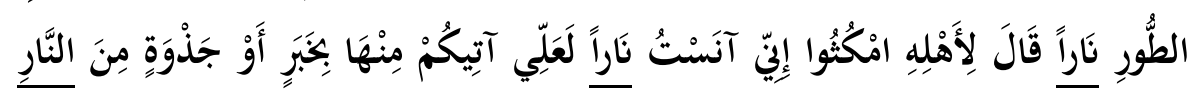

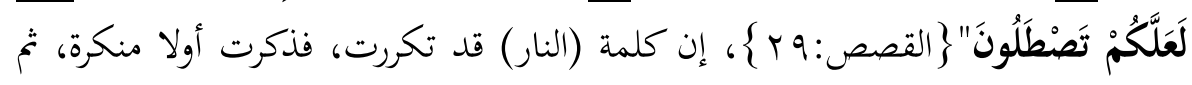
ذكرت ثانيا معرفة ب(أل) التي للعهد الذكري للربط بين الجملتين، والمعنى أن موسى عليه

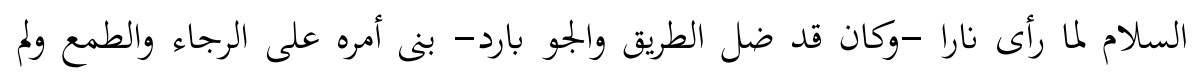
يقطع فقال(لعلي) راجيا أن يجد هناك جذوة يستدفئ بها أو هاديا يدله على الطريق، 
والآيتان معناهما واحد وصياغتهما قريبة جدا، فقد ذكرت (النار) فيهما منكرة ثم معرفة

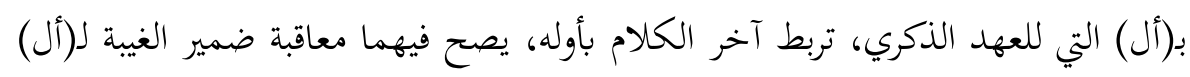
ومدخولها ، فيصح -في غير القرآن - أن تقول في الآيتين:

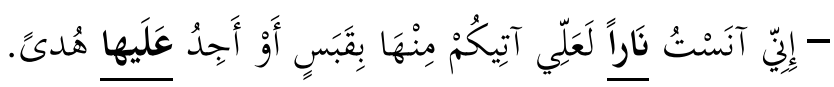

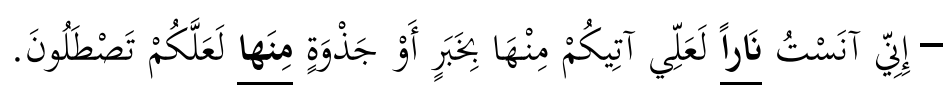

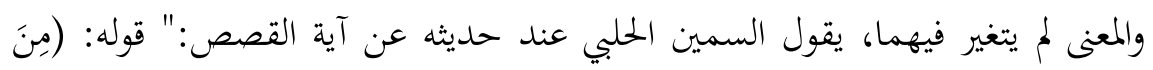

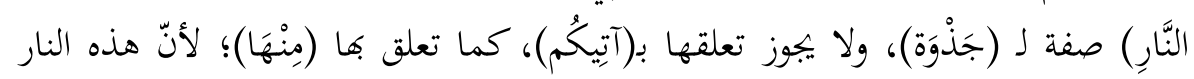

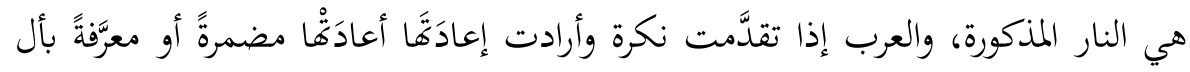

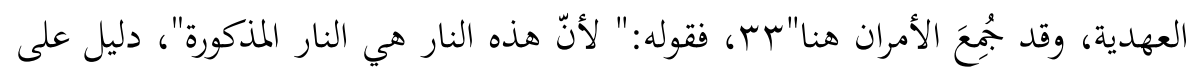
صحة المعاقبة مع ضمير (النار)، ولا يصح تعلق الجار والمجرور(من النار) بـ(آتيكم)؛ لأهنا

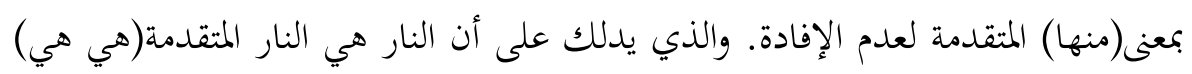

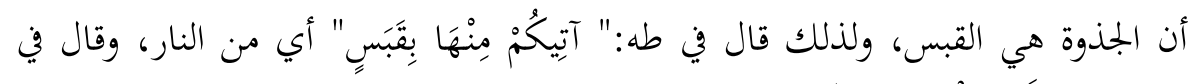

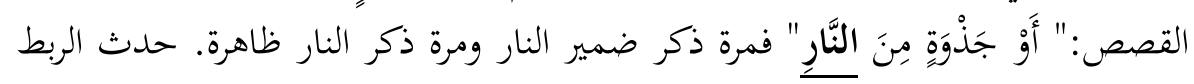

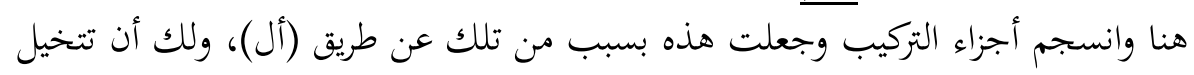

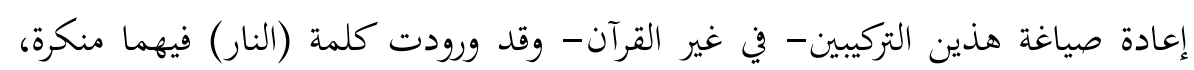

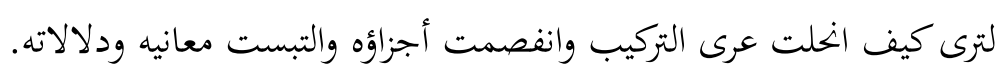

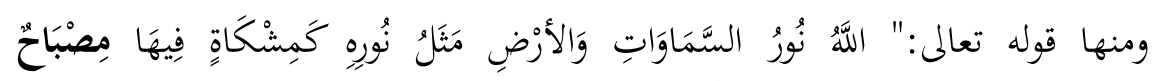

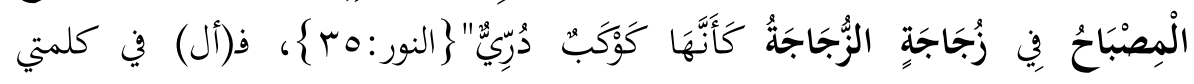

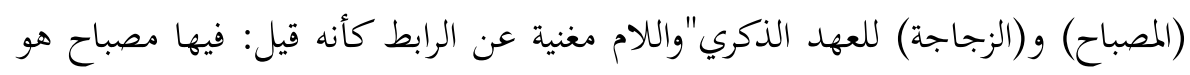

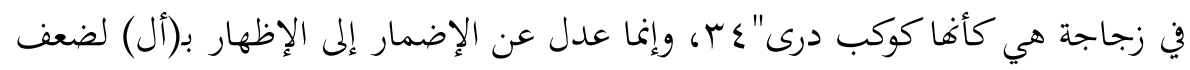

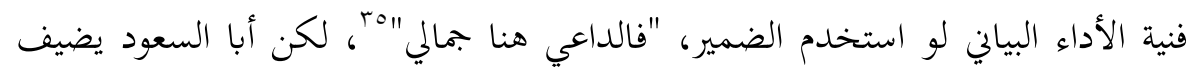

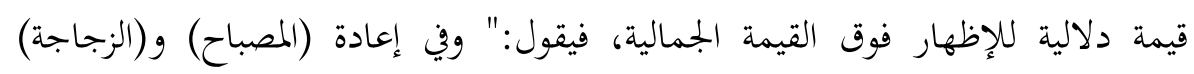

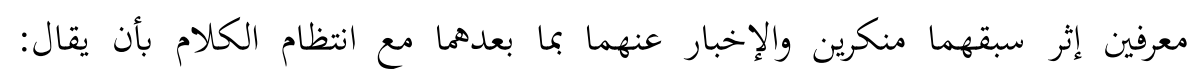

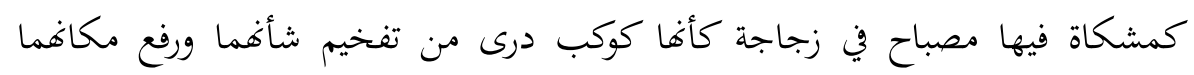

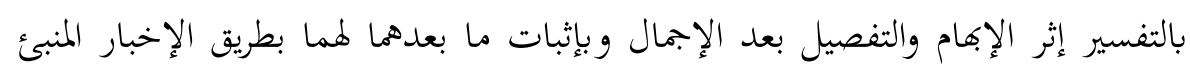

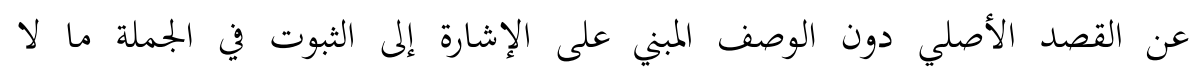
يخفي" "بن.

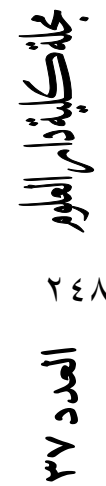




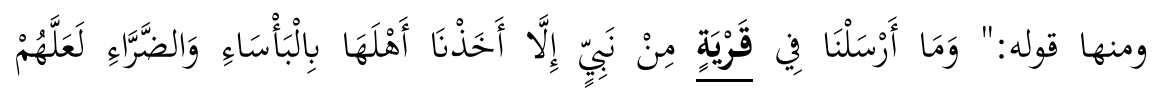

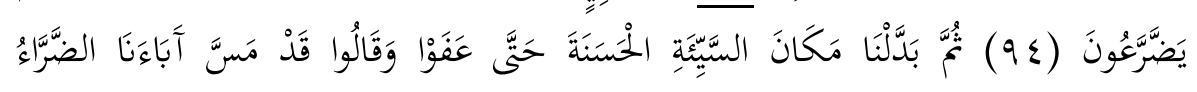

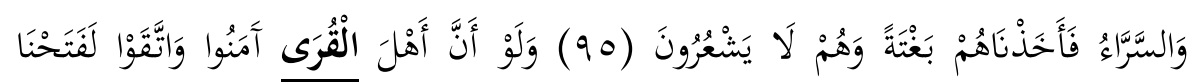

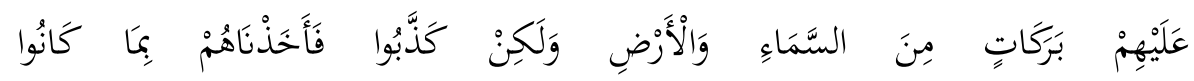

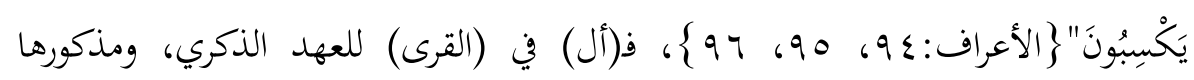

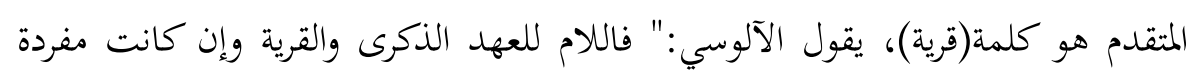

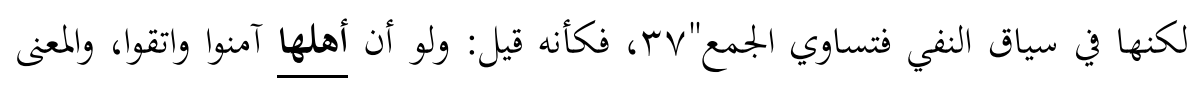

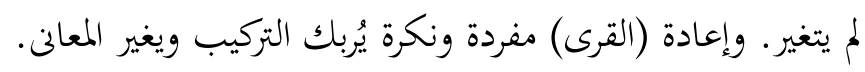

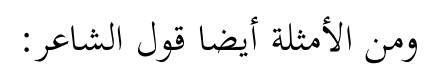

预

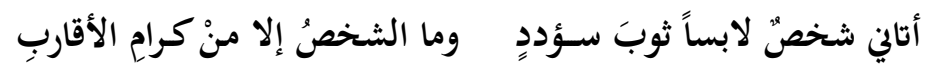
$r \leqslant q$

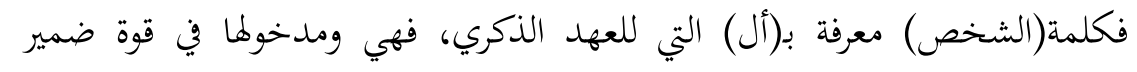

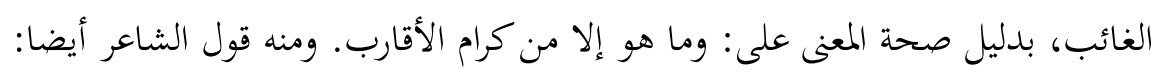

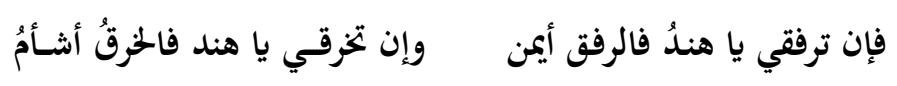

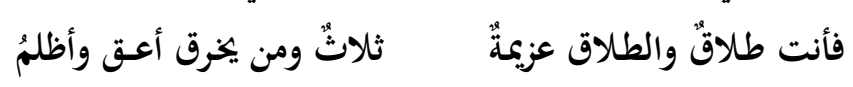

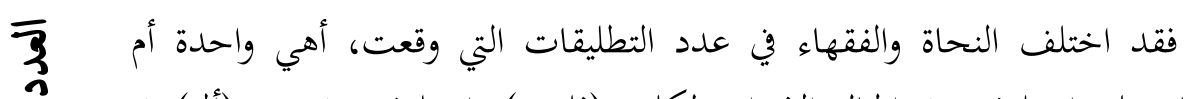

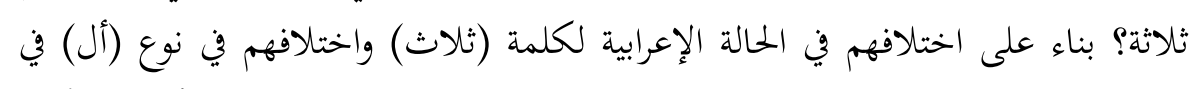

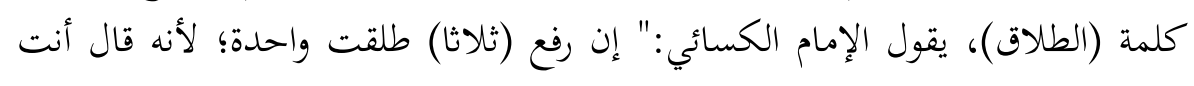

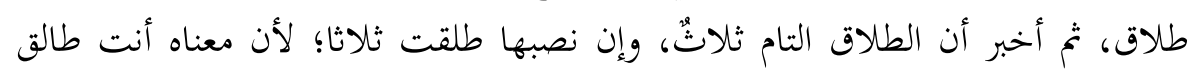

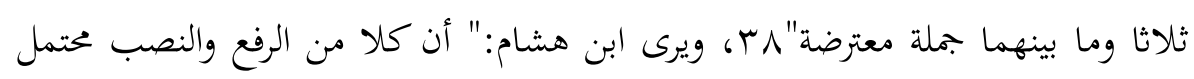

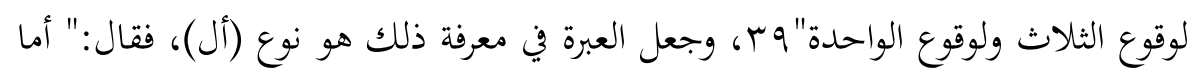

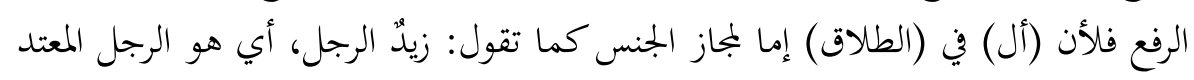

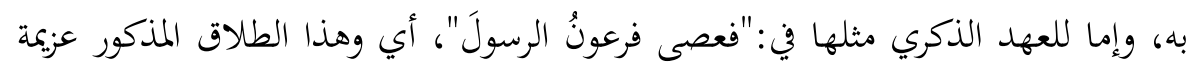

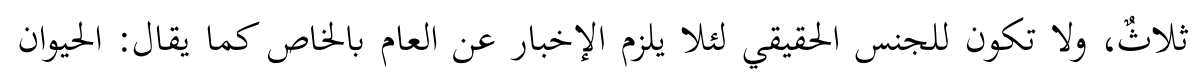

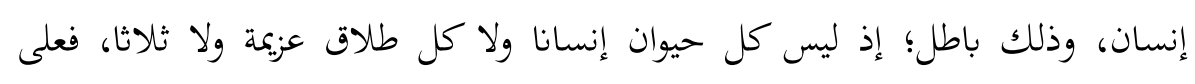

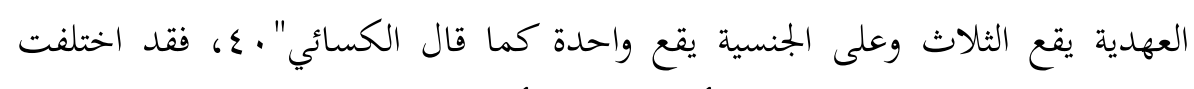

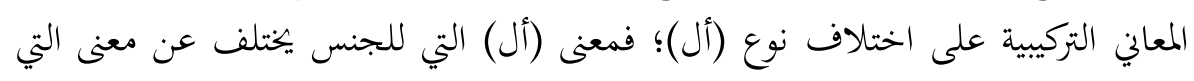


للعهد الذكري؛ لأن اعتبار الجنسية هنا يجعل لها دلالة الانفصال أو الاعتراض والقطع عما

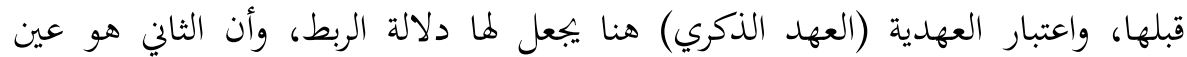

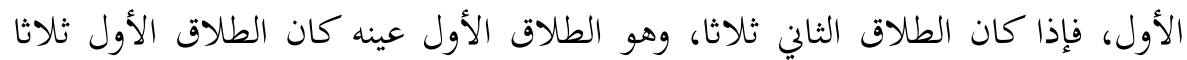

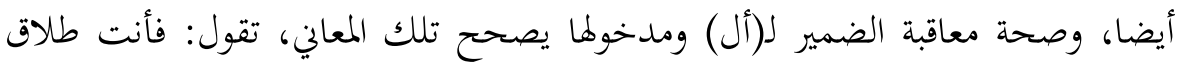

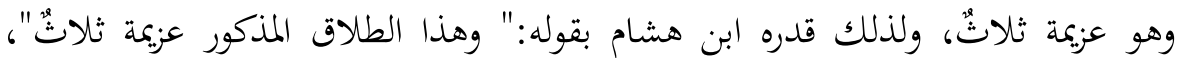

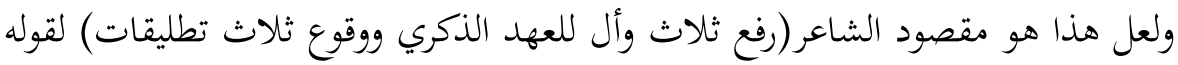

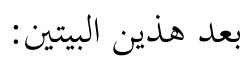

\section{وما لامرىء بعد الثلاث مقدم}

فبيني بما أن كنت غير رفين:

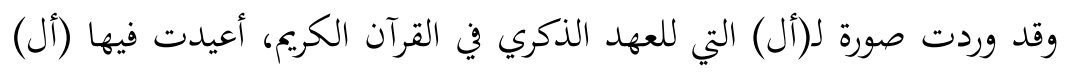

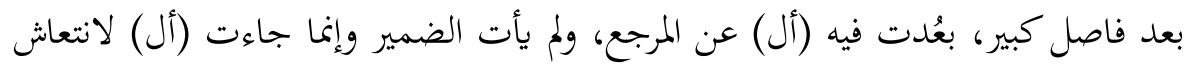

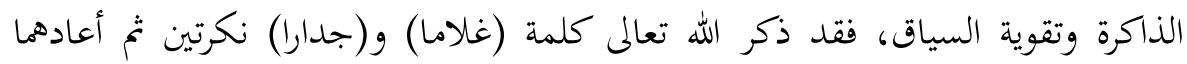

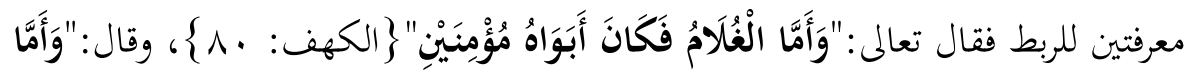

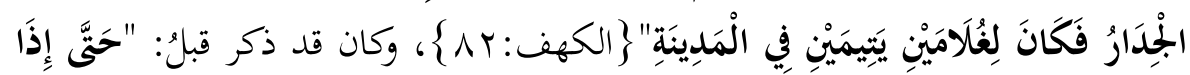

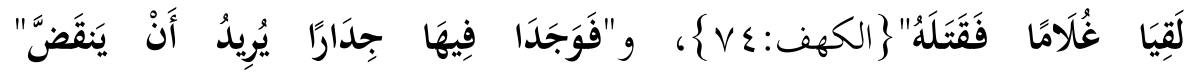

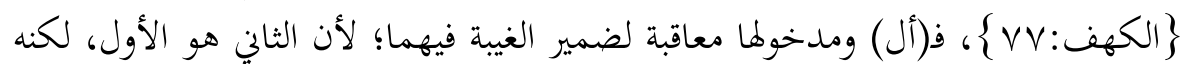

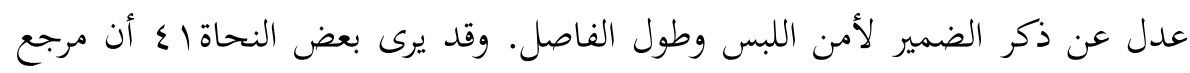

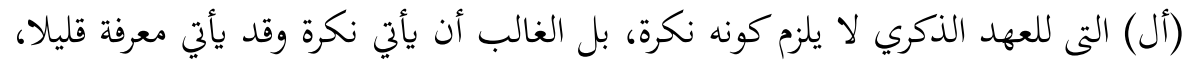

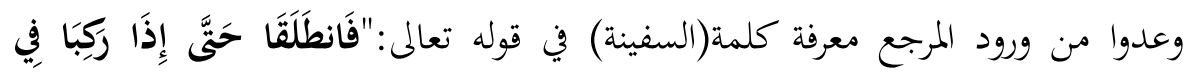
尔

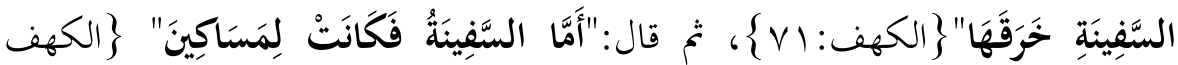
ج V9:

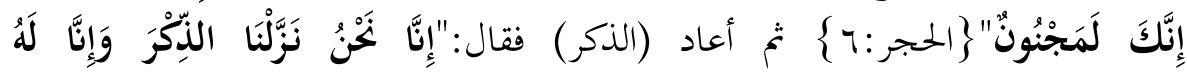

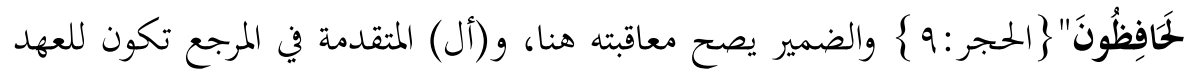

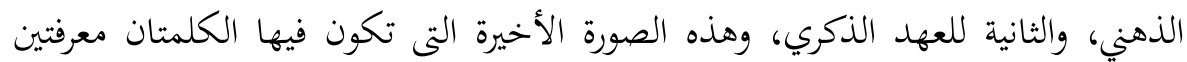

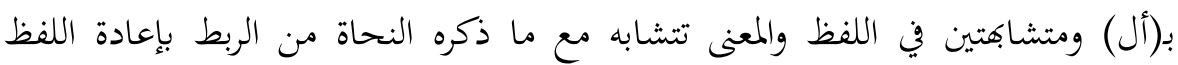

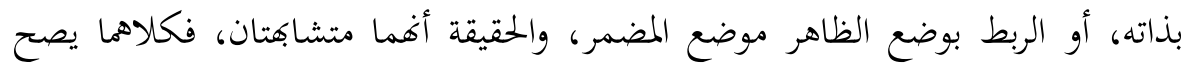

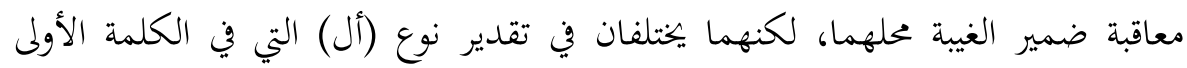

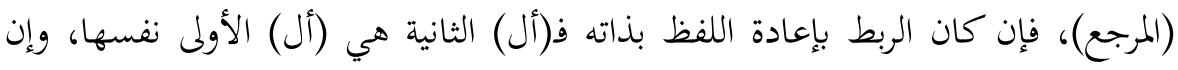

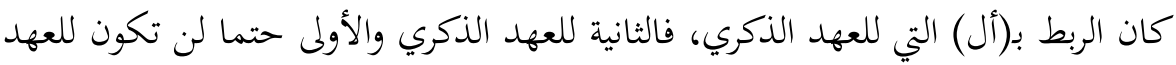




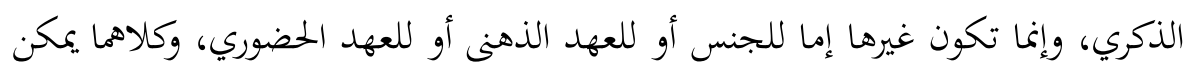

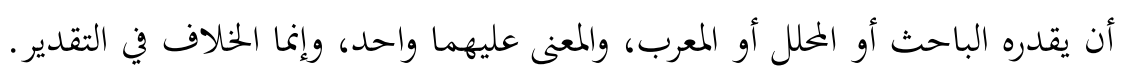

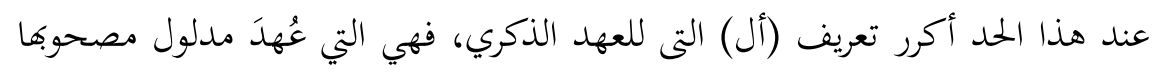

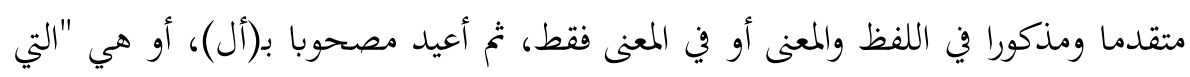

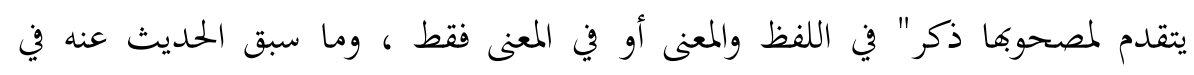

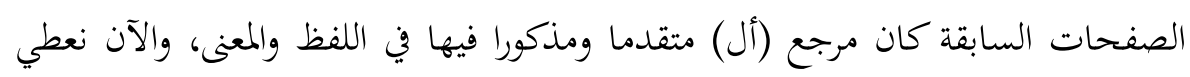

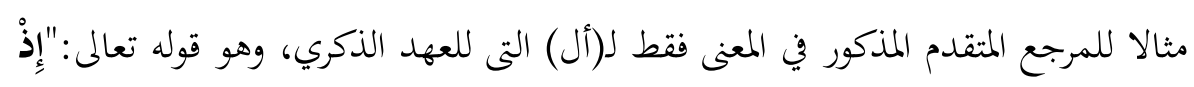

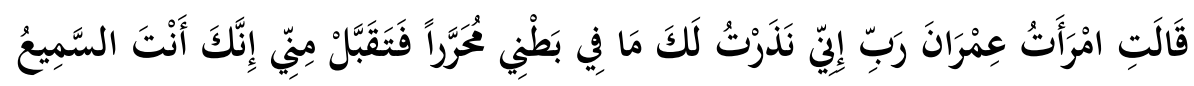

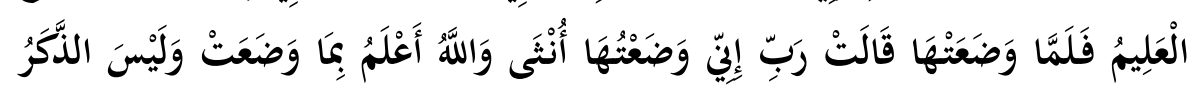

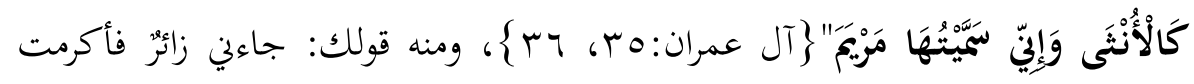

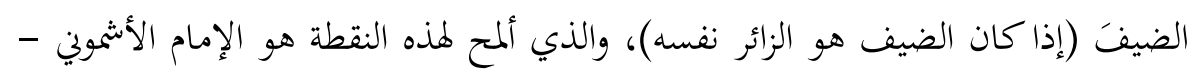

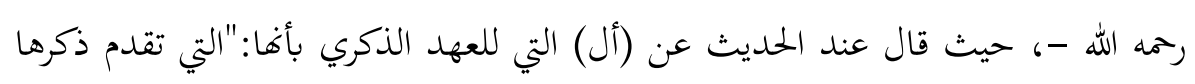

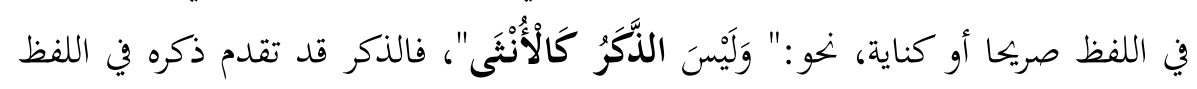

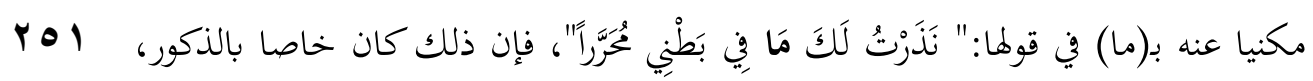

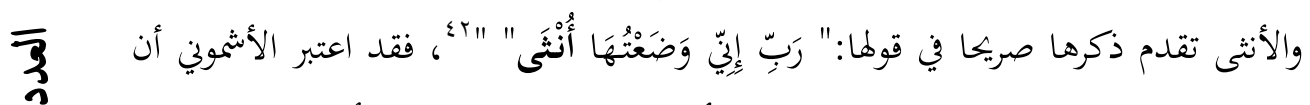

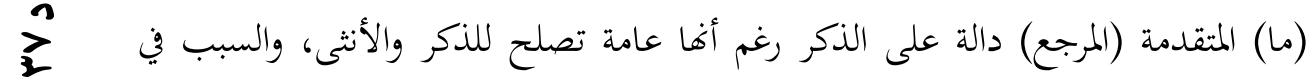
ذلك - كما قال الصبان- هو "تقييدها بـ(مررا)....؛ لأن (ما) باعتبار تقييدها بـ(محرا)

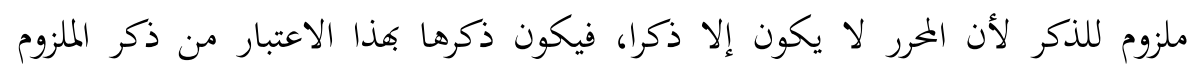

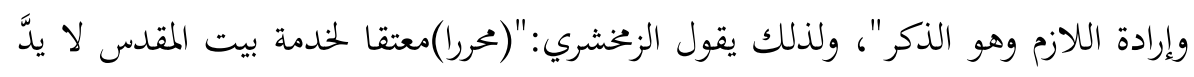
لي عليه ولا أستخدمه ولا أشغله بشيء... وما كان التحرير إلا للغلمان، وإنما بنت الأمر

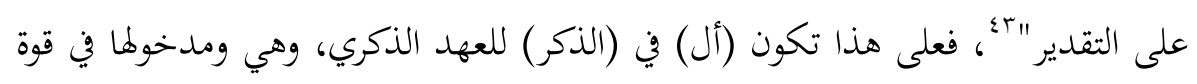

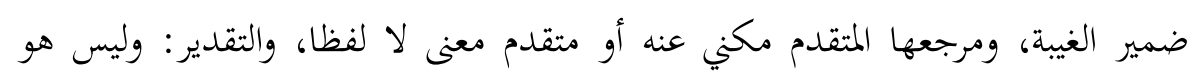
كهي، أي ليس الذكر كالأنثى.

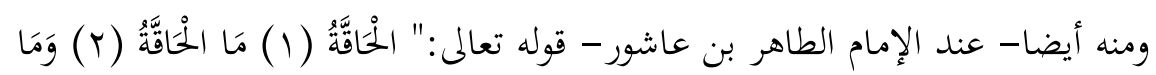

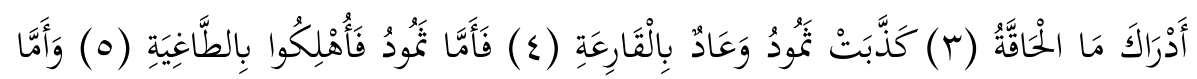




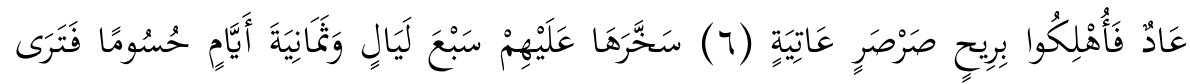

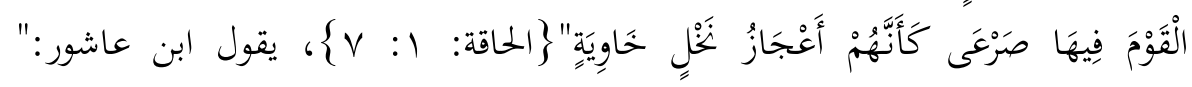

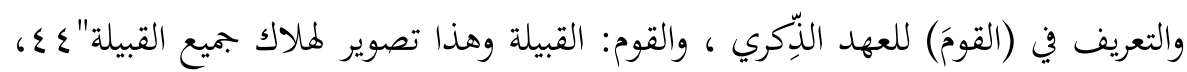

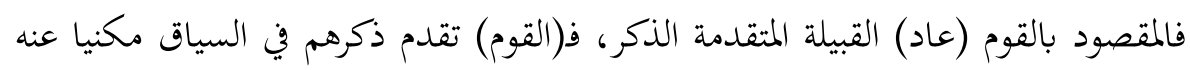
ب(عاد) أي: قوم عاد، يؤكد ذلك صحة معاقبة الضمير ل(القوم)، فتقول:(فتراهم)، ومنه

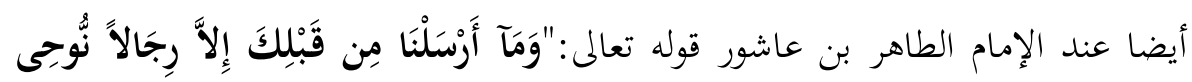

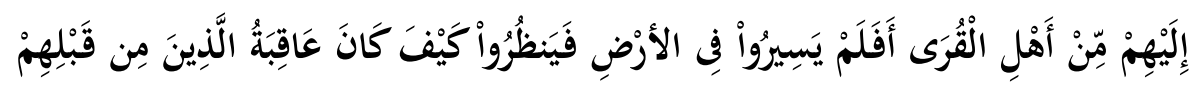

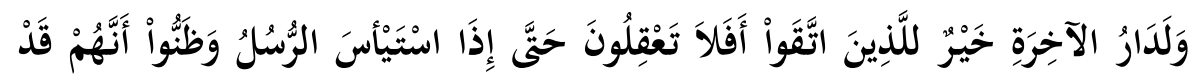

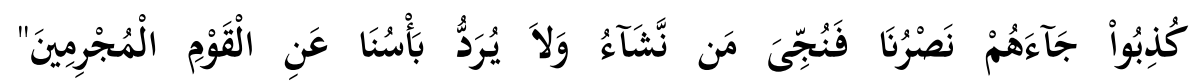

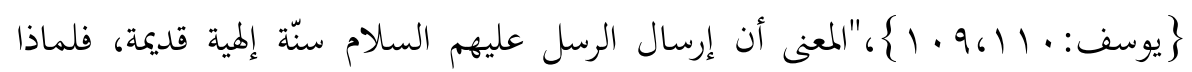

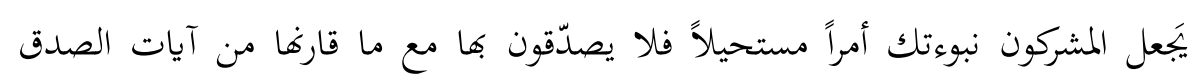

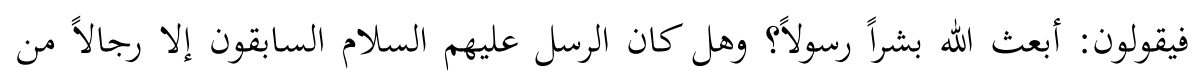
أهل القرى أوحى الله إليهم؟ فبماذا امتازوا عليك؟ فسلم المشركون ببعثتهم وتحدّثوا بقصصهم وأنكروا نبوءتك ... فالتعريف في (الرسل) عليهم السلام تعريف العهد الذكَريّ فئي

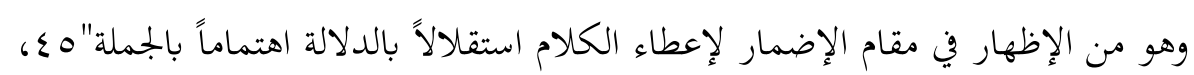

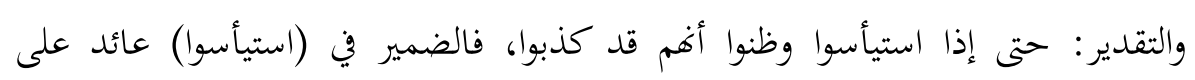

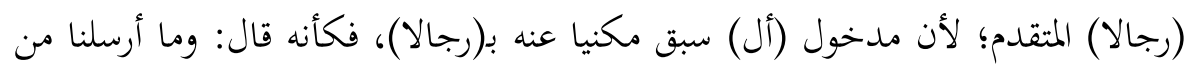
قبلك إلا رسلا من الرجال- بدليل فعل الإرسال- تم تكذيبهم وعنادهم حتى استيأسوا،

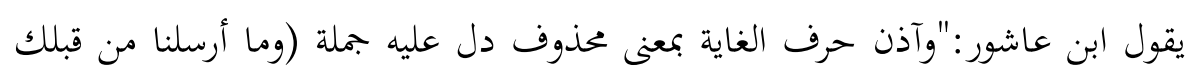
إلا رجالا) بما قصد بها من معنى قصد الإسوة بسلفه من الرسل عليهم السلام، والمعنى:

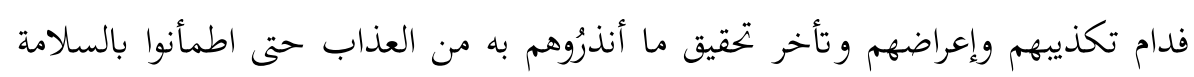

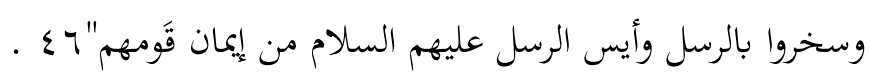

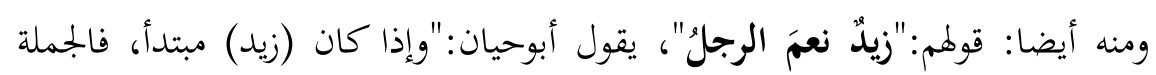

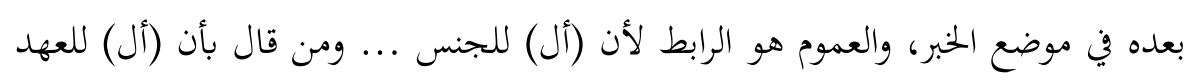

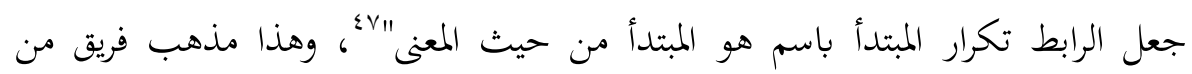


النحاةم؛، يجعل (أل) للعهد الذكري والمرجع المعهود هو "الشخص الممدوح والمذموم، فإذا

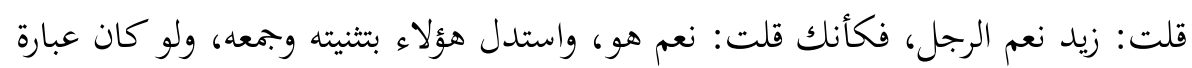

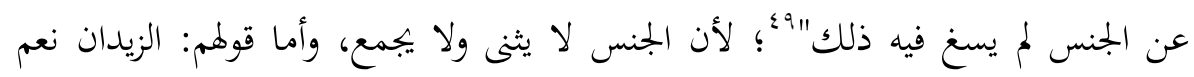

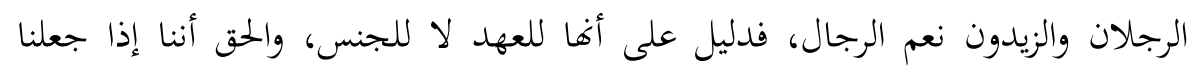
(أل) للعهد الذكري كان الرجل هو عين (زيد) فجاز أن يكون الربط بإعادة المبتدأ بمعناه

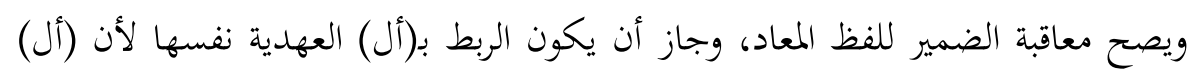

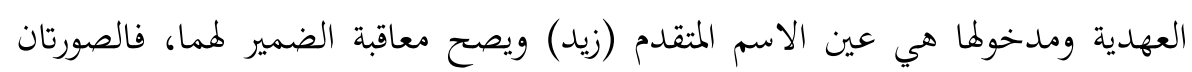

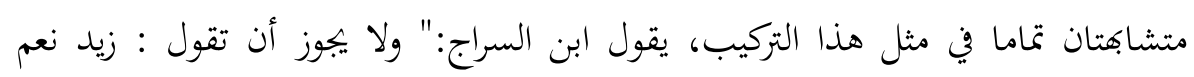

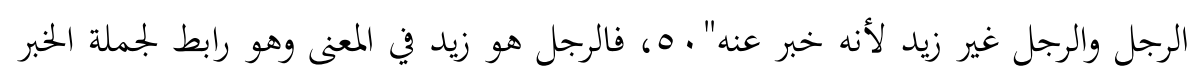
بالمبتدأ (المرجع)، و(أل) هي التي للعهد الذكري وهي رابطة لجملة الخبر بالمبتدأ (المرجع)

$$
\begin{aligned}
& \text { أيضا، فيكون الاحتمالان واردين كما في الشكل الآتي: }
\end{aligned}
$$

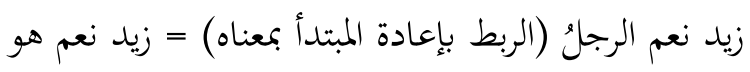

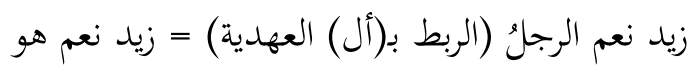

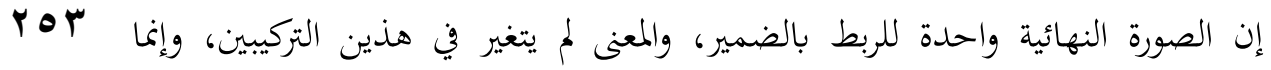

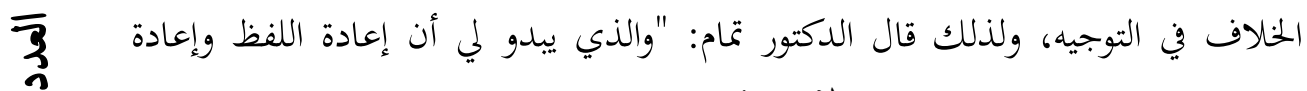

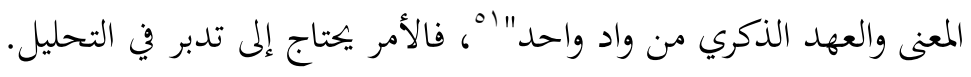

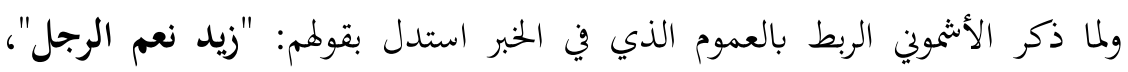

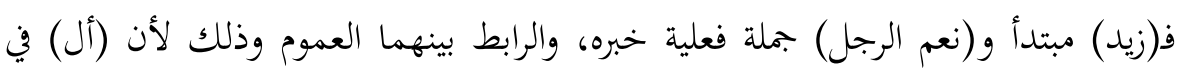

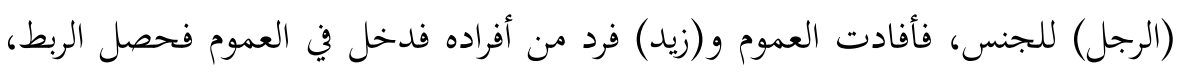

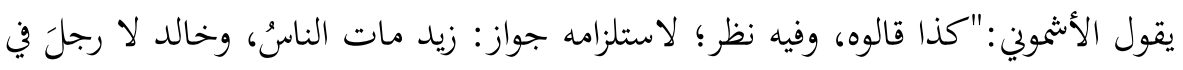

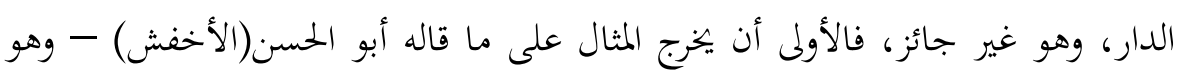

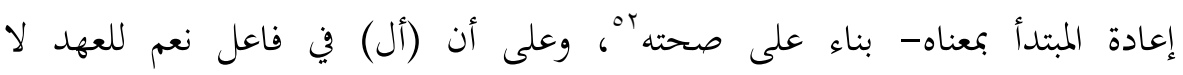

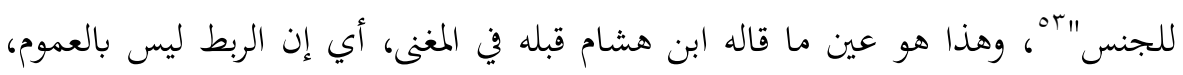

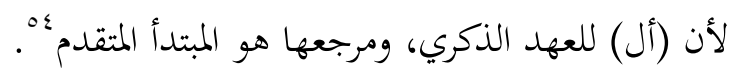


هذا، وقد وجدت رأيا قيما لابن عاشور في كتابه "التحرير والتنوير"، أرى أن أختم به

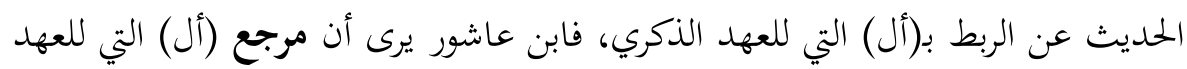

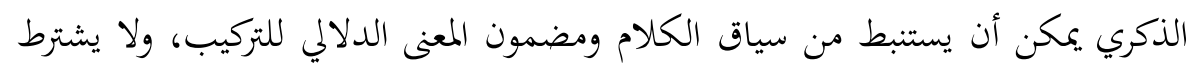

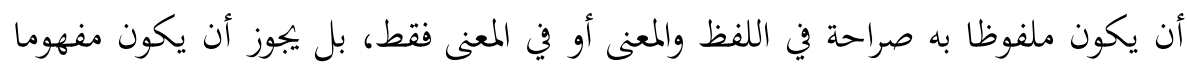

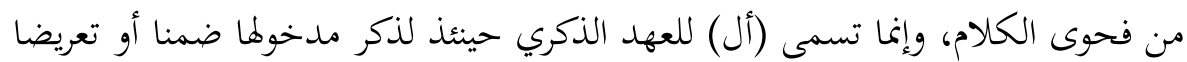

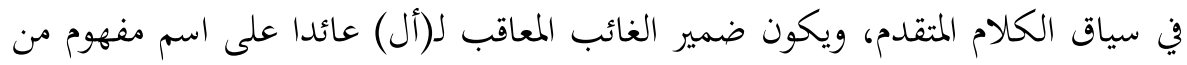

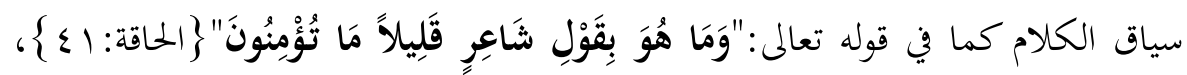

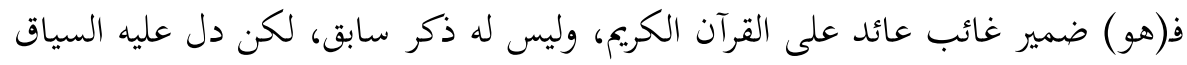

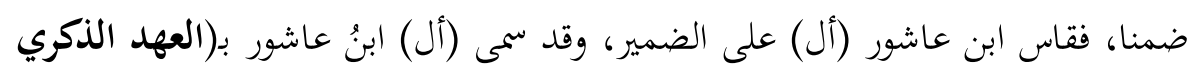

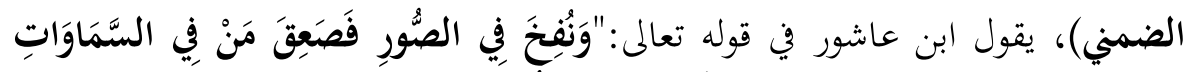

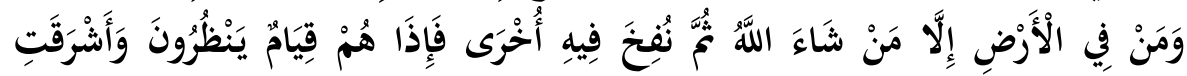

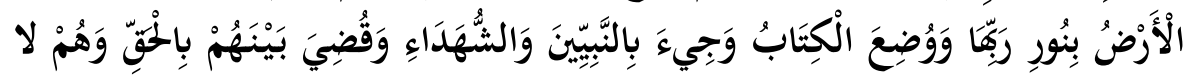

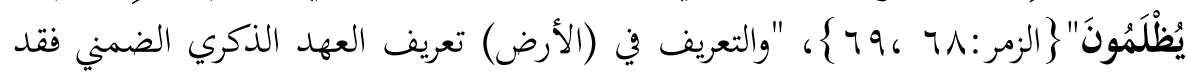

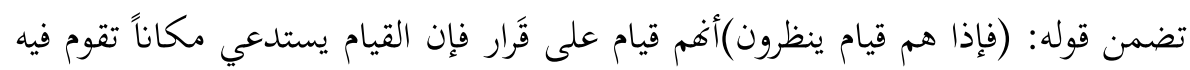

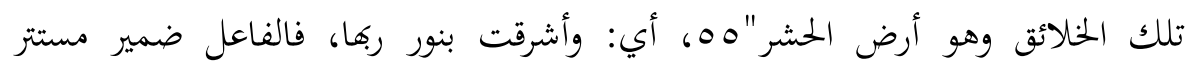

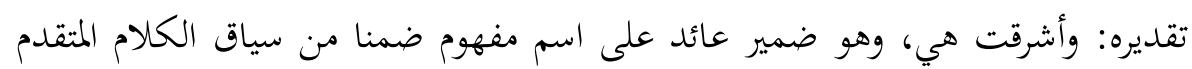

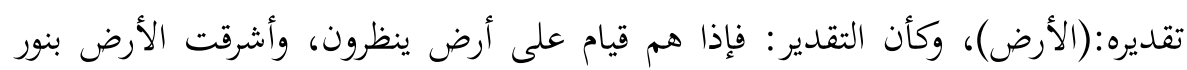

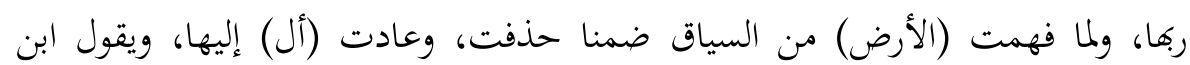
势 ros

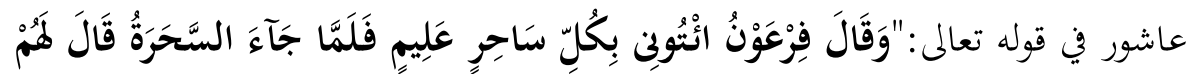

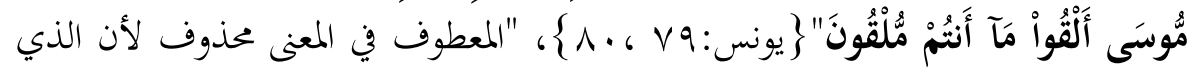

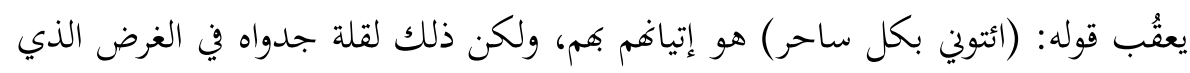

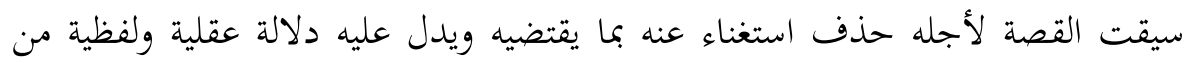

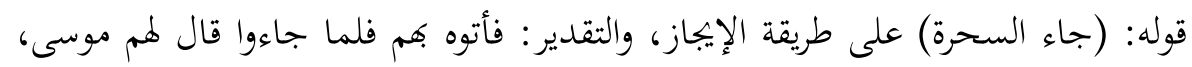

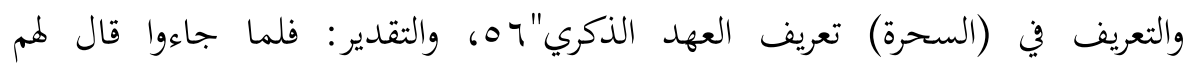
، فالضمير في (جاءوا) عائد على اسم متقدم دل عليه سياق الكلام تقديره: (السحرة)،

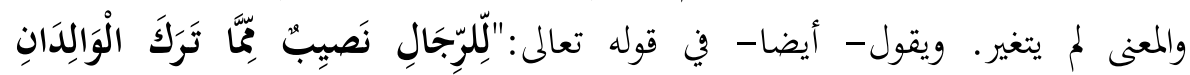

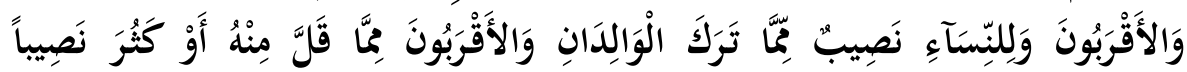

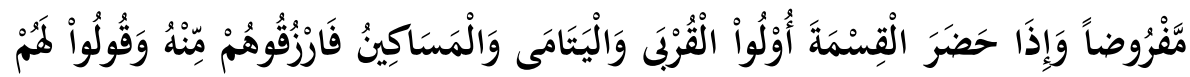

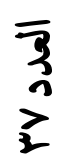




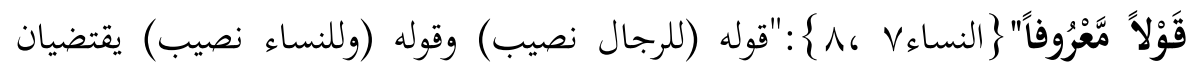

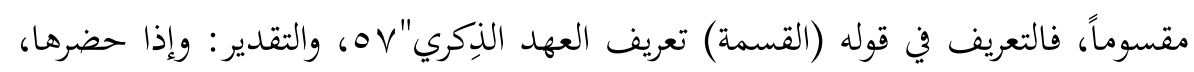

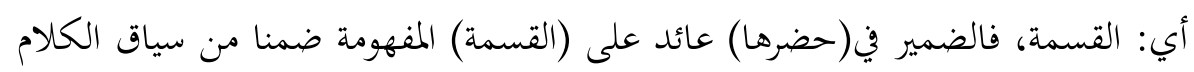

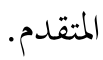
فإذا ما أخذنا في الاعتبار كلام ابن عاشور المتقدم، -وهو كلام وجيه حمله على الضمير

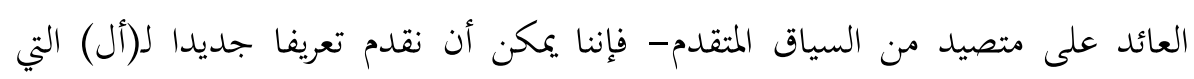
للعهد الذكري بأها "هي التي سبق ذكر مدخولها صريحا لفظا ومعنى، أو سبق ذكره صريها معنى فقط، أوسبق ذكره ضمنا في سياق الكلام".

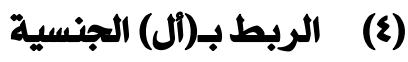

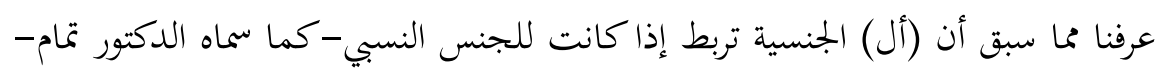

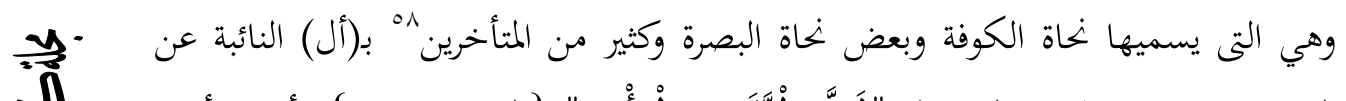

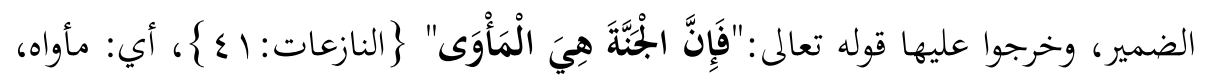

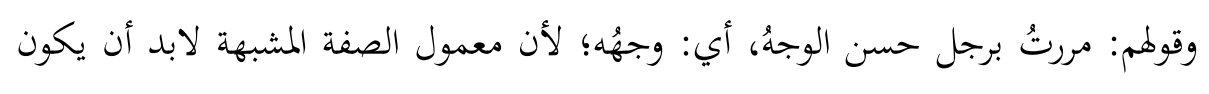

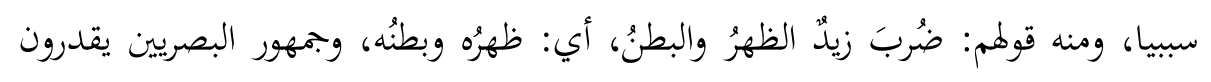

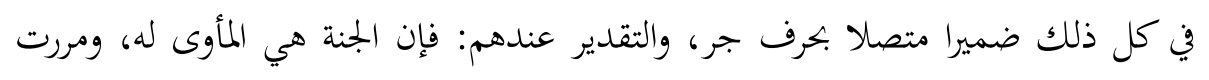

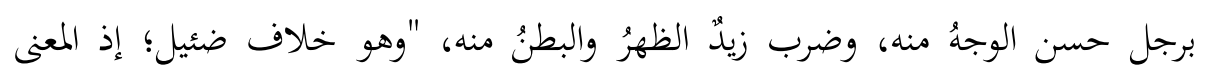

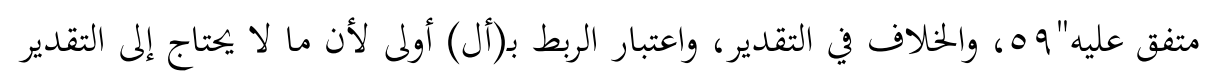

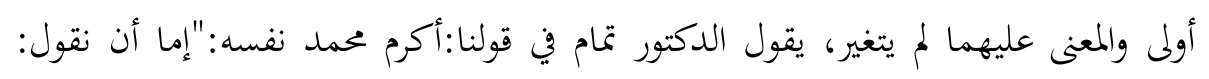

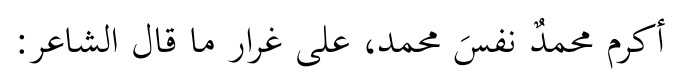

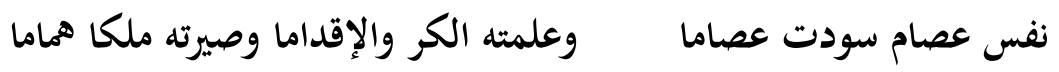
وعلى نحو ما في قوله عليه الصلاة والسلام:"لو أن فاطمة بنت محمد سرقت لقطع محمدٌ

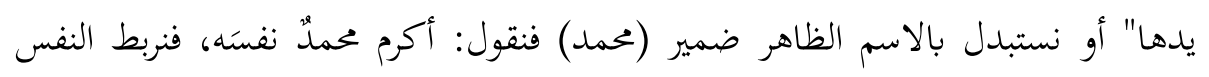

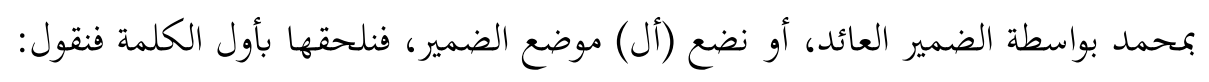

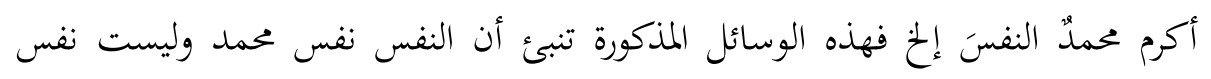

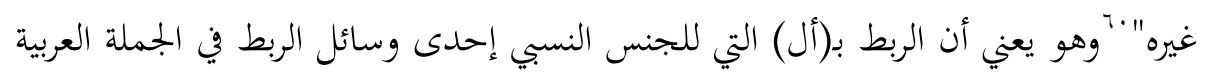

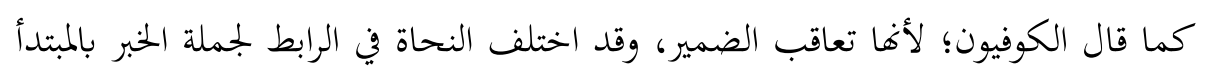




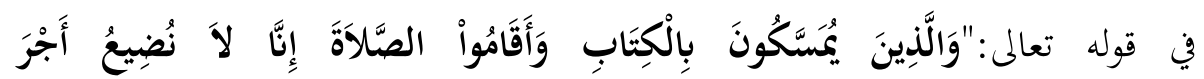

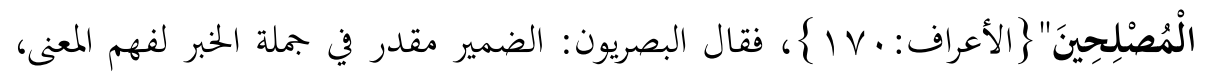

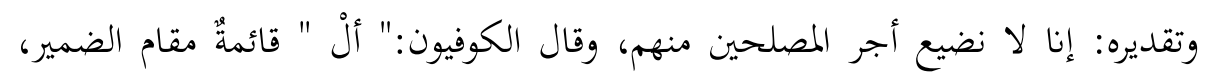

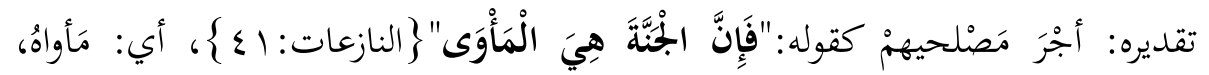

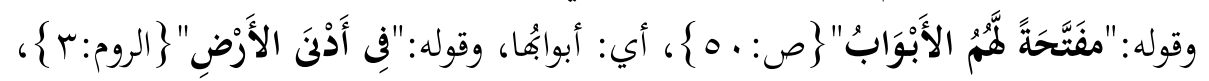

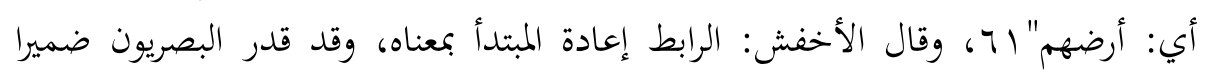

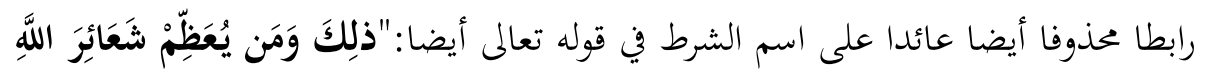

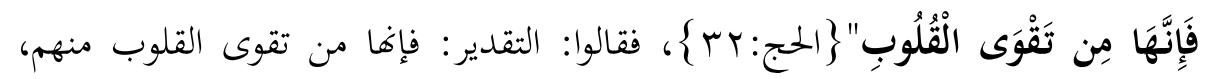

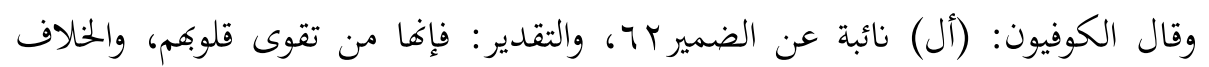

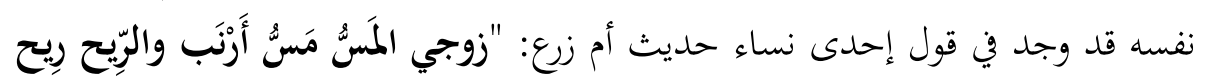

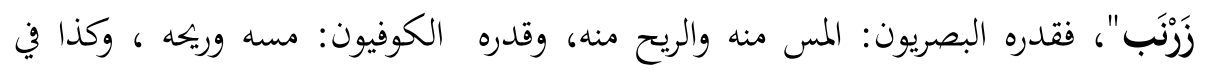

من الناس، فالأحلامُ غيرُ عوازب قول النابغة:

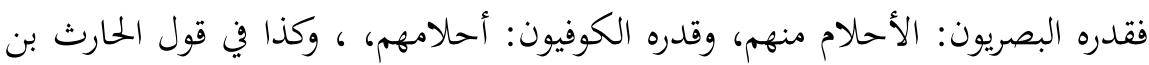
كلدة:

\section{لمَم شيمةُ لمُ يعطها اللهُ غيرَهم}

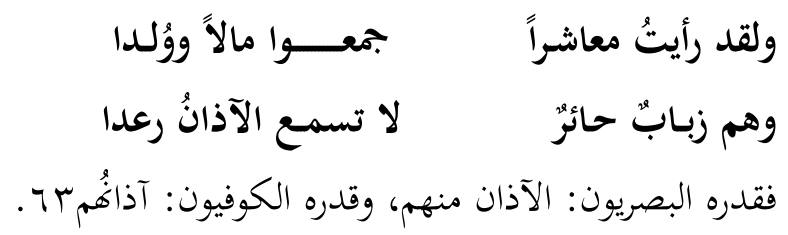

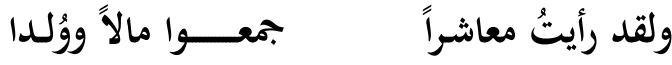

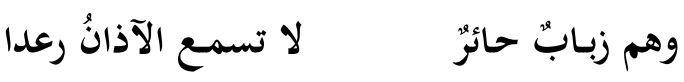

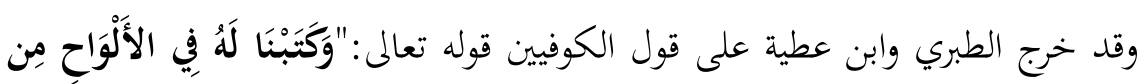

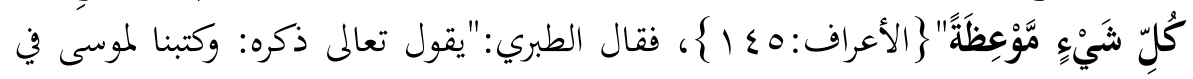

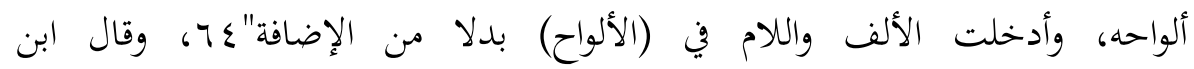

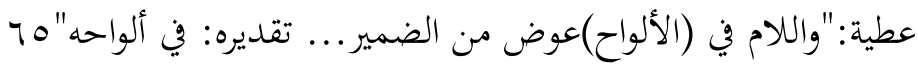

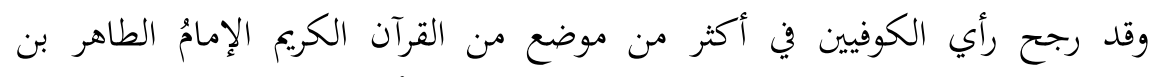

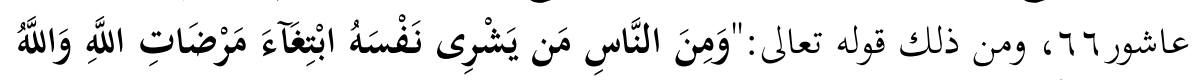

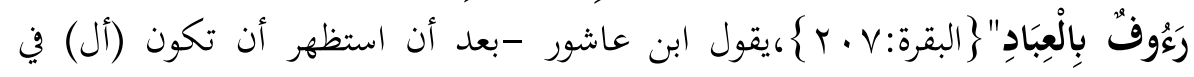

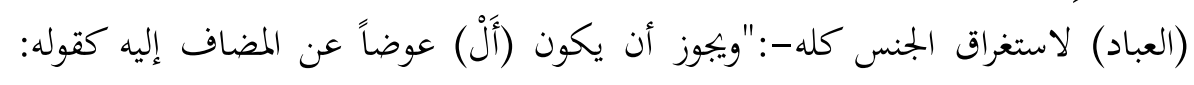




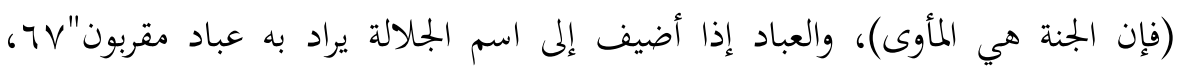

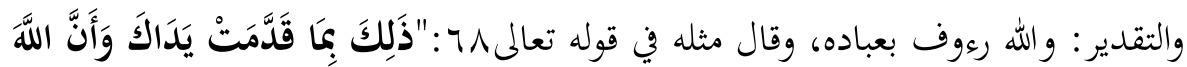

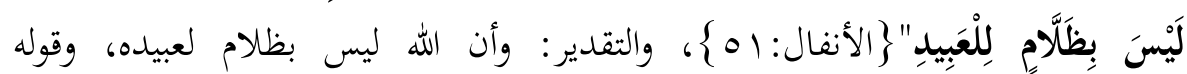

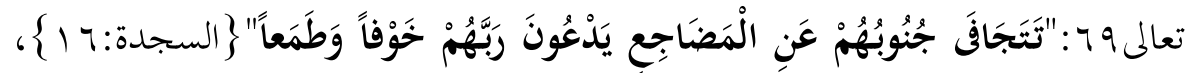

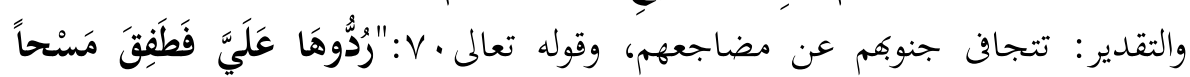

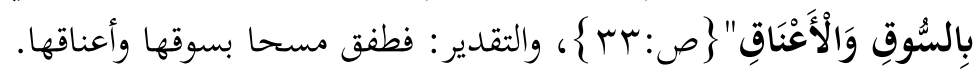

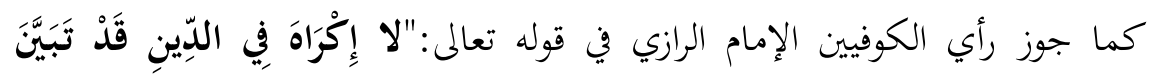

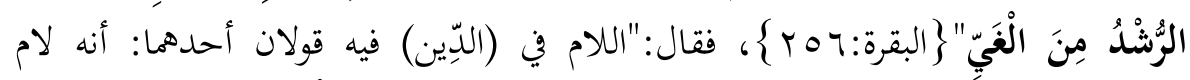

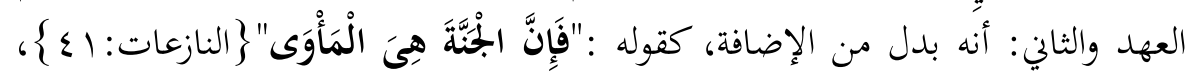

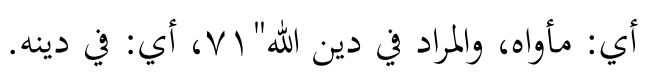

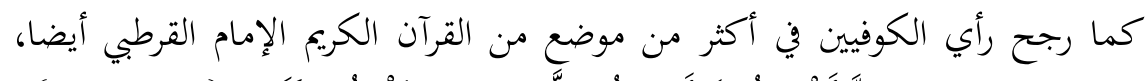

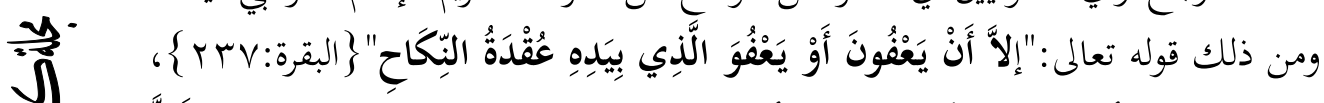

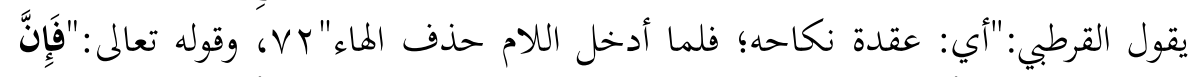

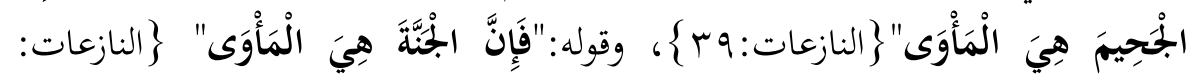

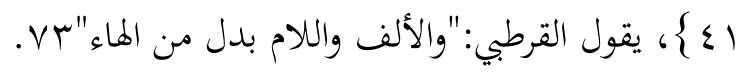
Y०V

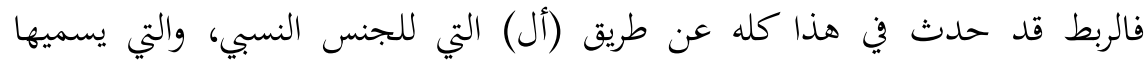

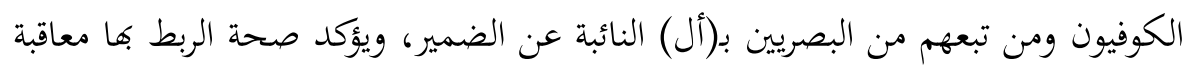

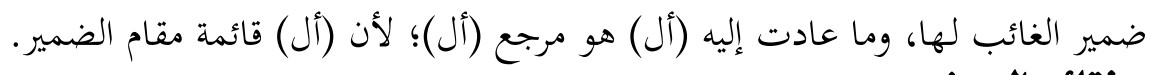
نتائج البحث: بعد الحديث عن الربط بـ(أل) التعريفية خلص البحث إلى الى ما يأتي:

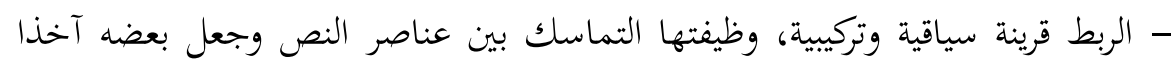

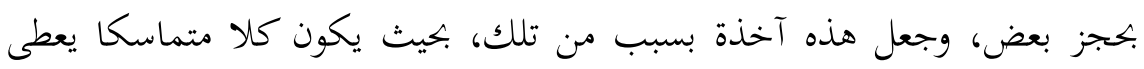

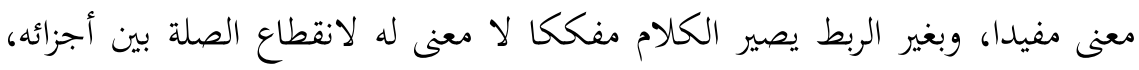

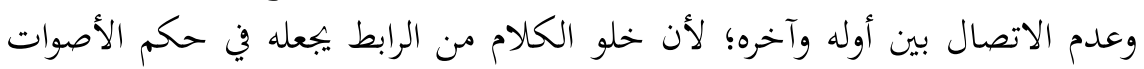

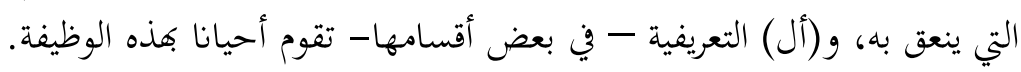

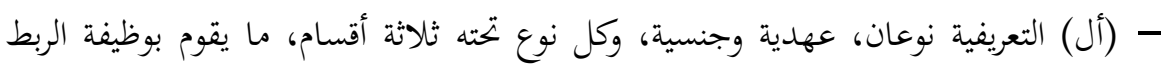

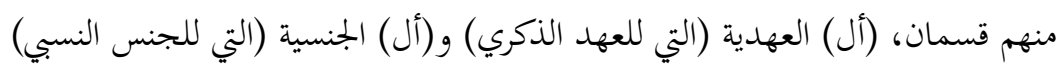


- (أل) التي للجنس النسبي هي الداخلة تحت ما أطلق عليه النحاة (أل) الجنسية التي لتعريف الماهية.

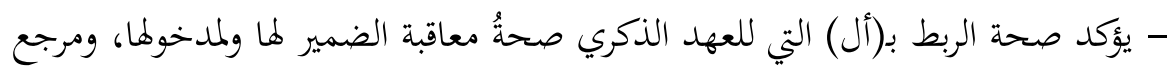

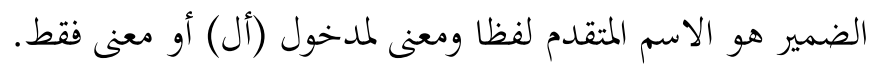

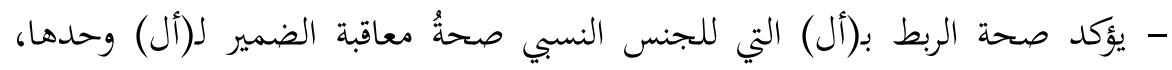
ومرجع (أل) هو ما عاد عليه الضمير المعاقب لـ ألل).

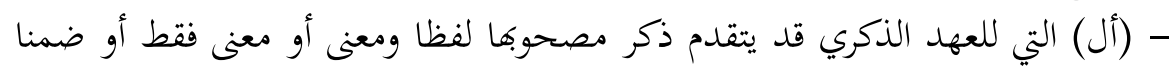

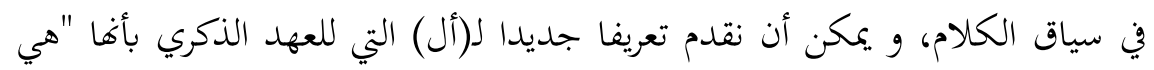

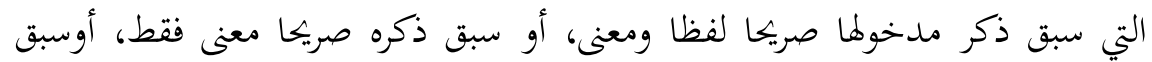
ذكره ضمنا في سياق الكلام".

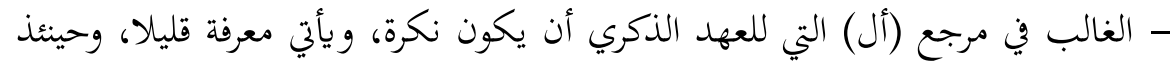

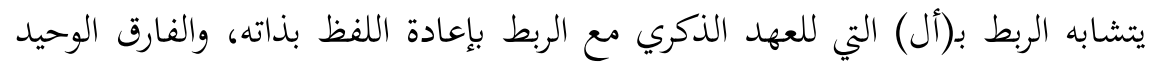

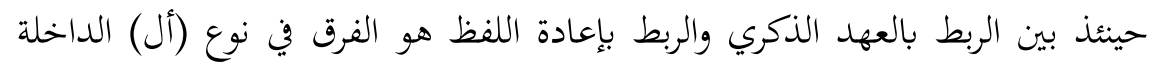

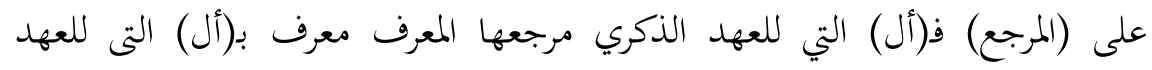

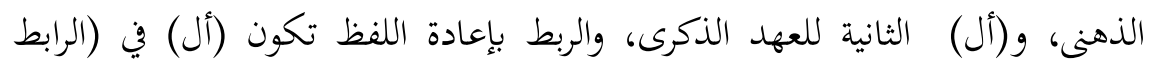

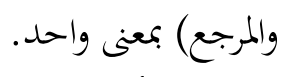

- الربط ب(أل) التي للجنس المعادي النسبي هو مذهب الكوفيين وبعض البصريين وكثير من

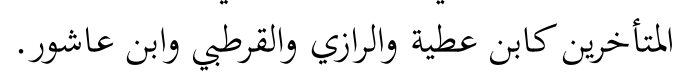

\section{المصادر والمراجع}

- ارتشاف الضرب من لسان العرب، لمحمد بن يوسف المعروف بأبي حيان الأندلسي

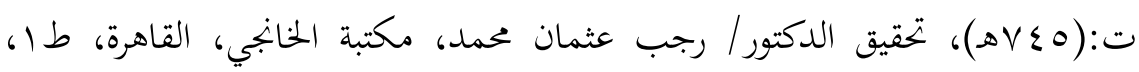

$$
\text { 1991. أها }
$$

- الأصول في النحو، لأبي بكر محمد بن سهل بن السراج (ت:7 آبهـ)، تحقيق عبد

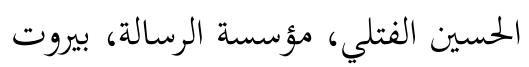

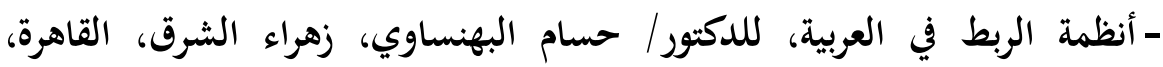

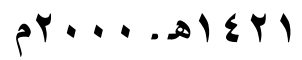

- ائتلاف النصرة في اختلاف نحاة الكوفة والبصرة، لعبد اللطيف بن أبي بكر الشرجي

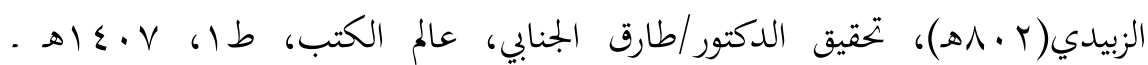




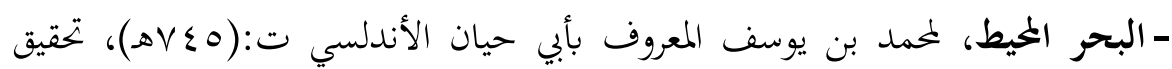

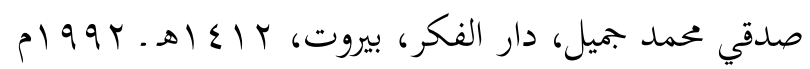

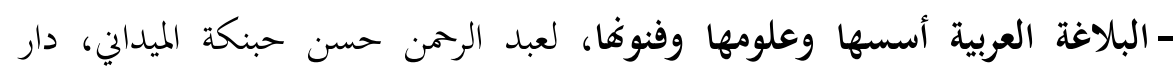

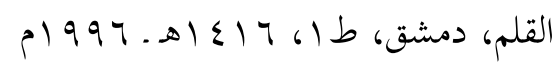

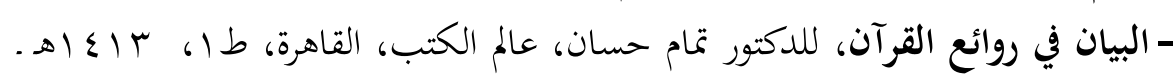
م 1994 - البيان في غريب إعراب القرآن، لأبي البركات بن الأنباري(ت:ه Vه Vه)تحقيق د. طه

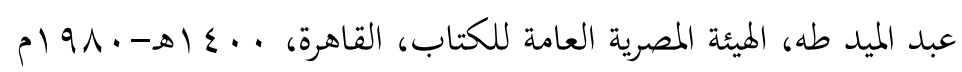

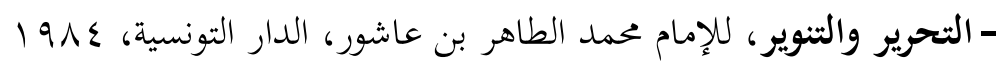

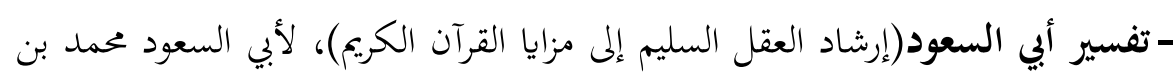

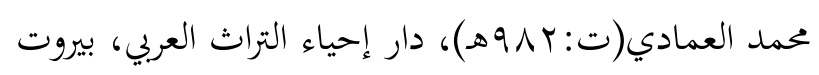

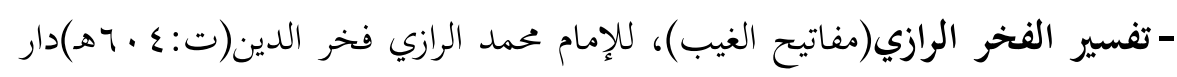

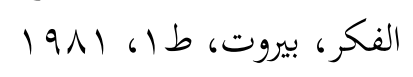

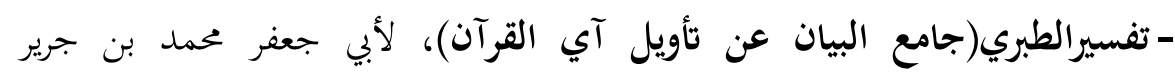

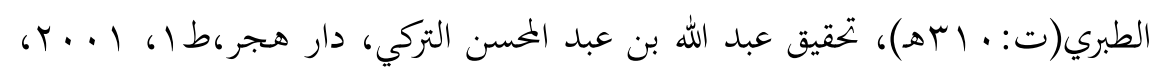
القاهرة

$\overline{3}$ - الجامع لأحكام القرآن، لأبي عبد الله محمد بن أحمد الأنصاري القرطبي (ت: الح آهـ)،

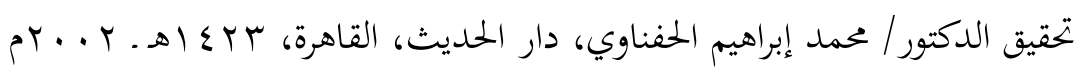

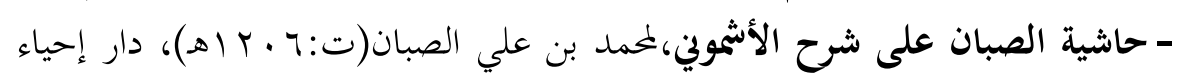

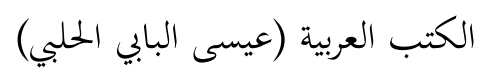

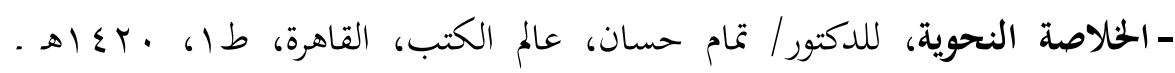

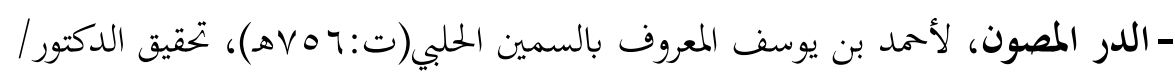

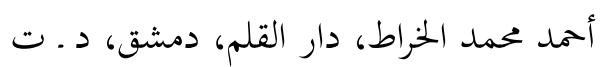

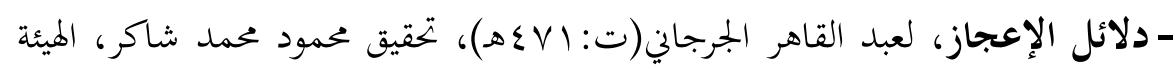

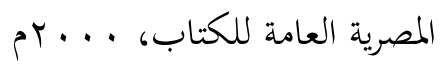

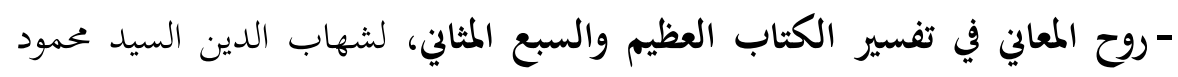

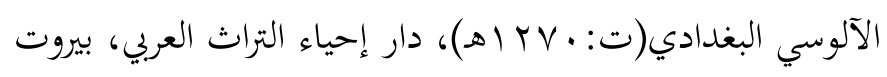


- سبيل المدى بشرح قطر الندى، للشيخ محمد مي الدين عبد الحميد (مطبوع على هامش شرح قطر الندى)، دار الأقصى، القاهرة

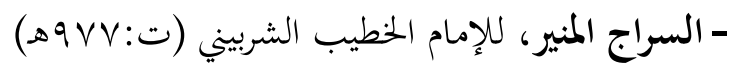
- شرح الأشمولي، دار إحياء الكتب لإم العربية (عيسى البابي الحلبي)

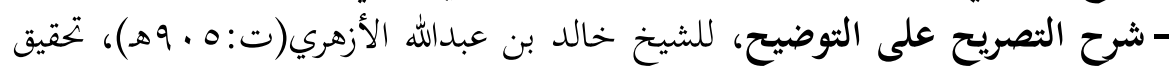

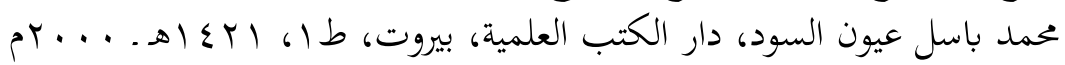

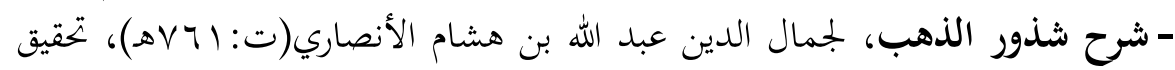

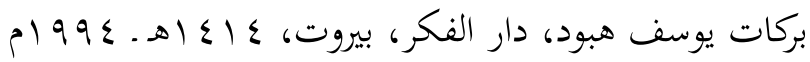

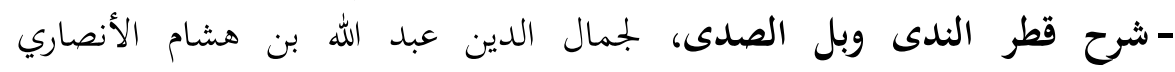

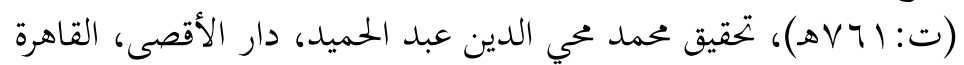

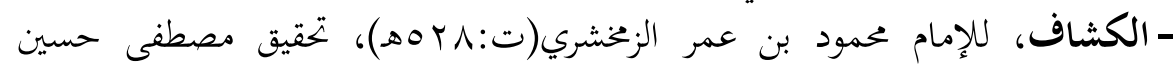

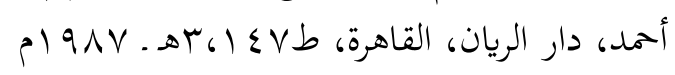

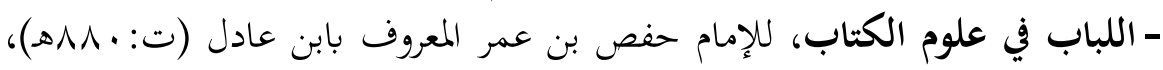

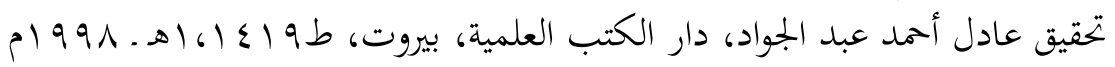

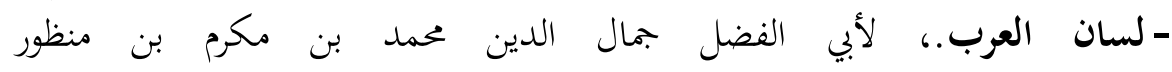

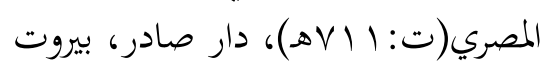

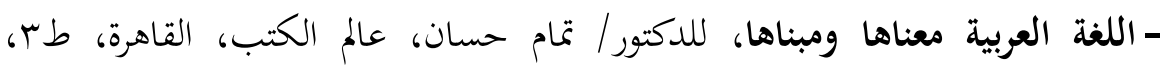

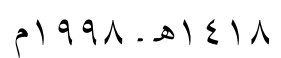

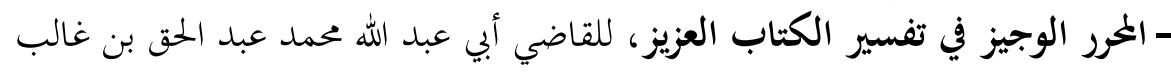

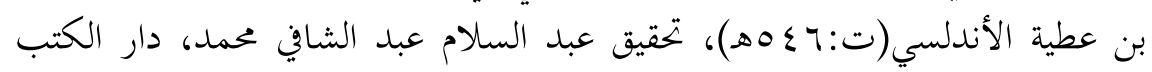

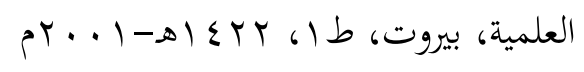

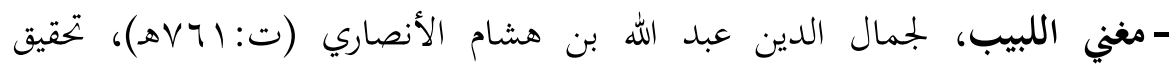

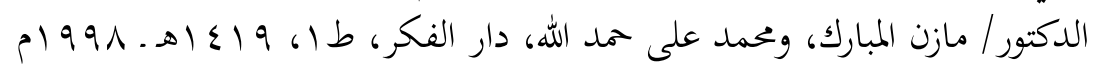

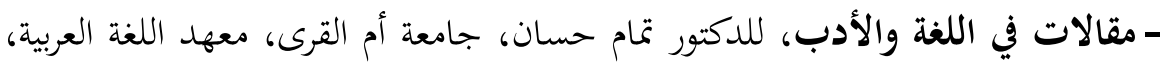

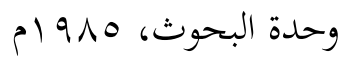
- الموقعية في النحو العربي، للدكتور/ حسين رام رفعت، عالم الكتب، القاهرة، طا،

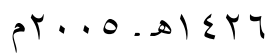

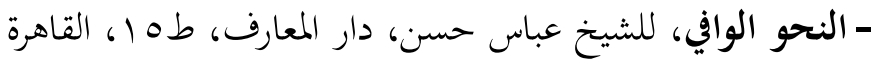

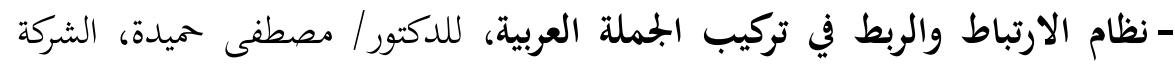

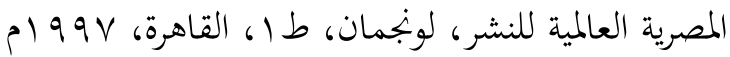




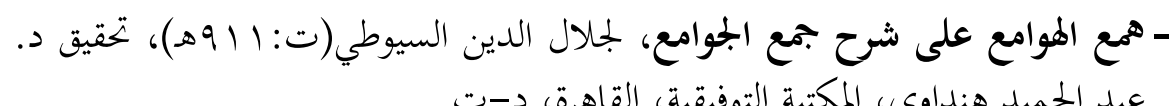

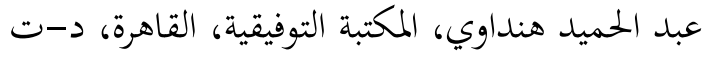

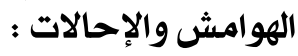

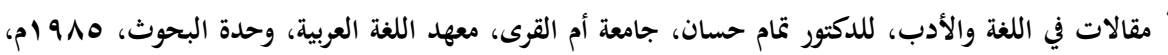

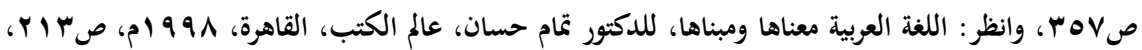

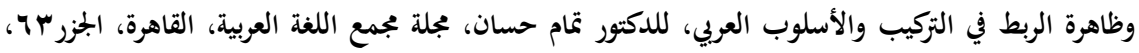

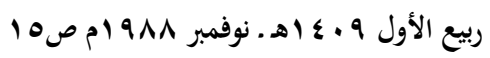

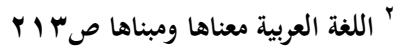

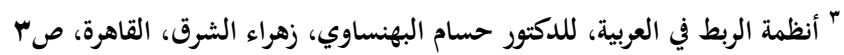

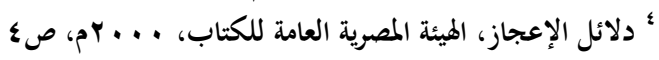

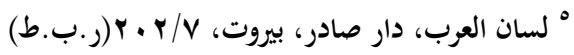

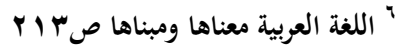

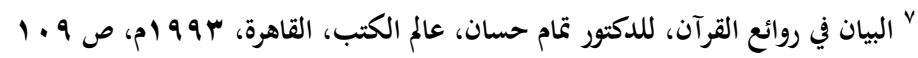

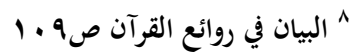

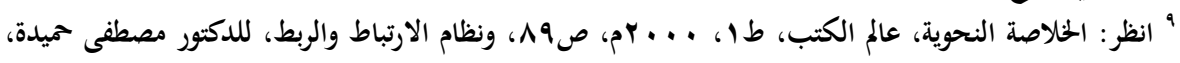

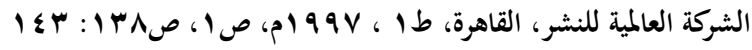

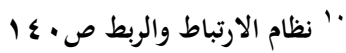

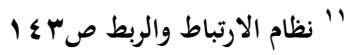

rY

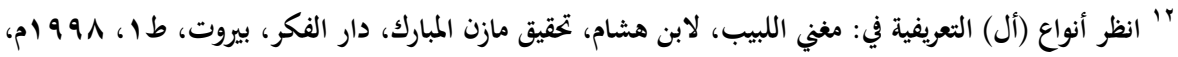

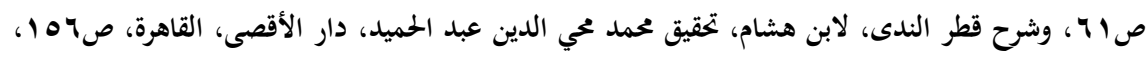

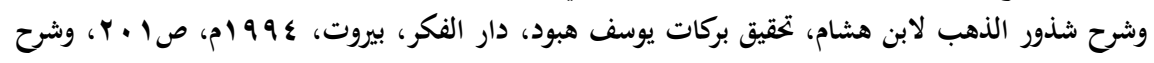

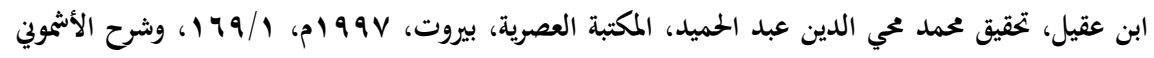

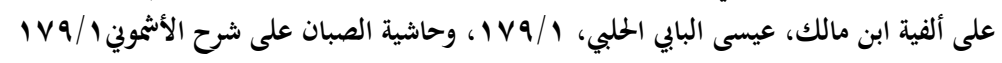

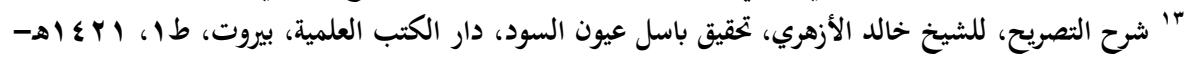

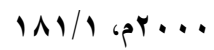

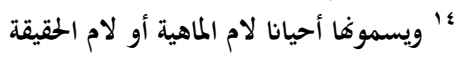

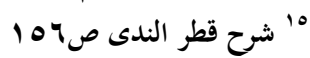

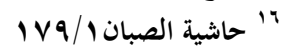

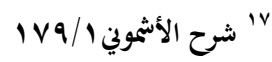

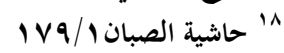
19 سبيل الهدى بشرح قطر الندى، لخمد محي الدين عبد الحميد، مطبوع على هامش شرح قطر الندى، ص 104، $10 \mathrm{~V}$

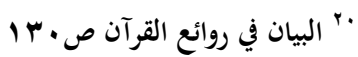

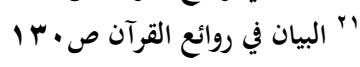

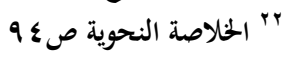




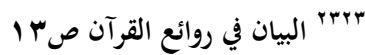

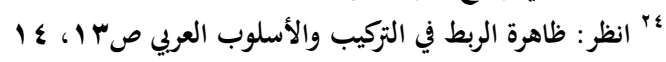

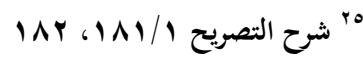

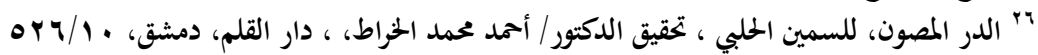

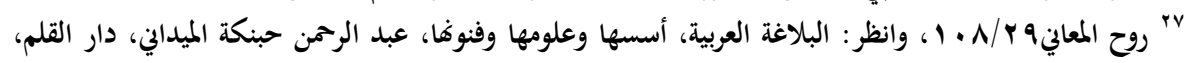

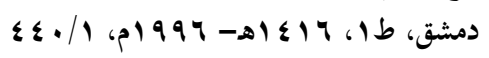

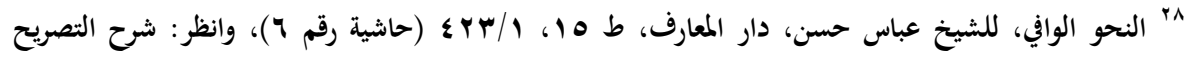

$1 \wedge r / 1$

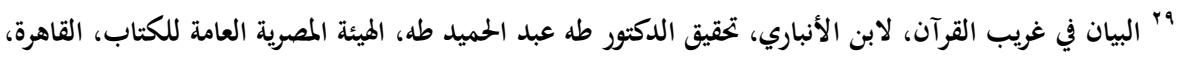

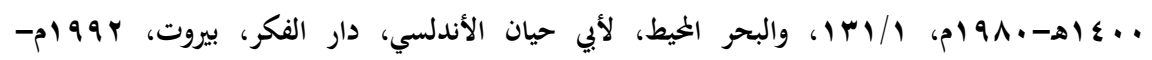

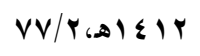

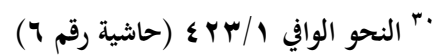

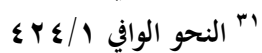

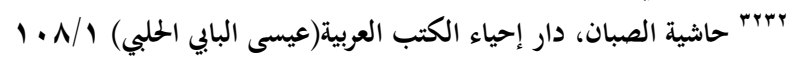

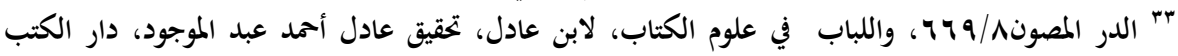

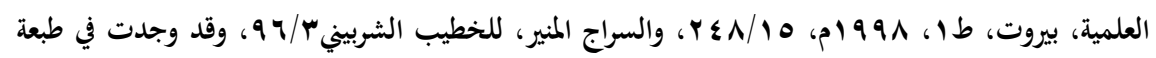

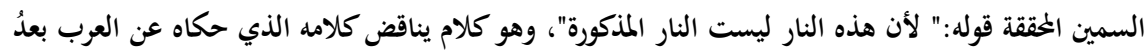

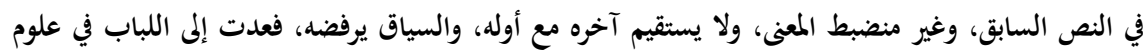

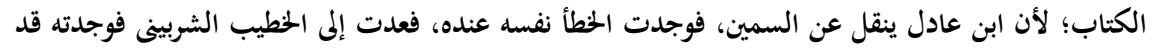

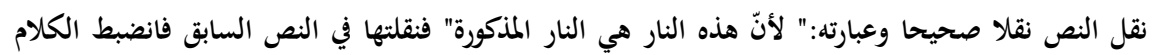

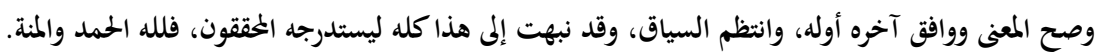

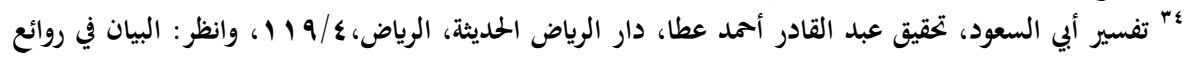

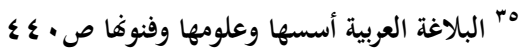

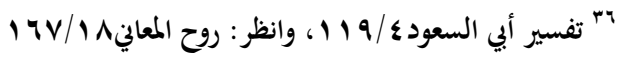

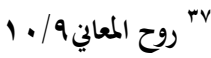

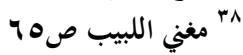

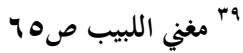

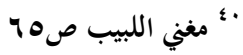

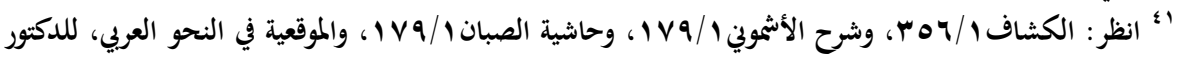

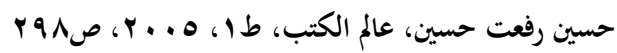

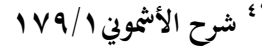

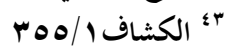

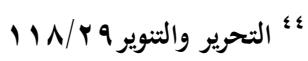

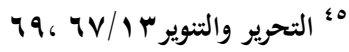




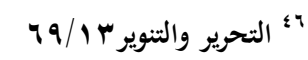

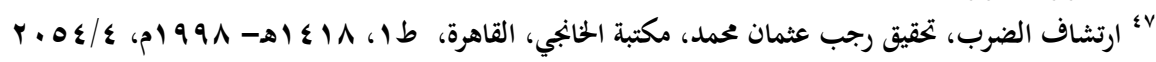

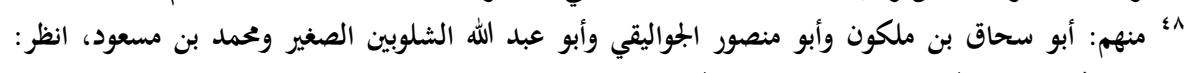

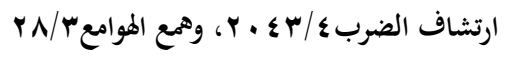

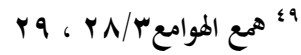

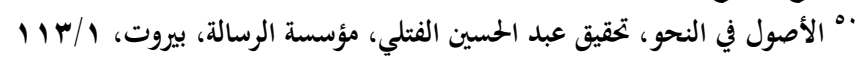

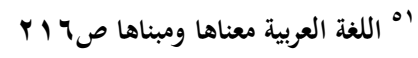

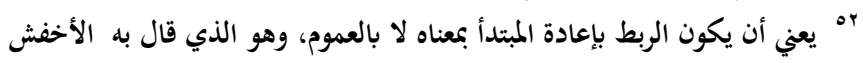

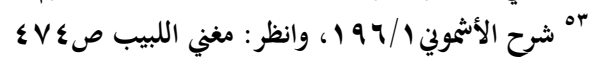

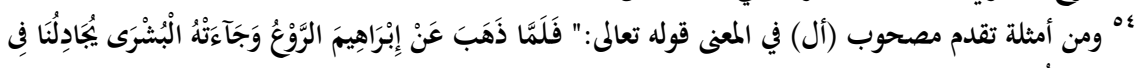

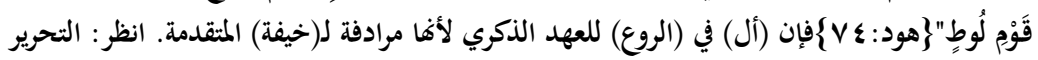

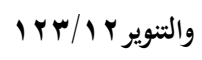

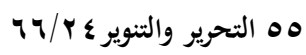

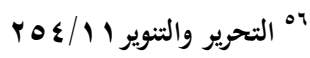

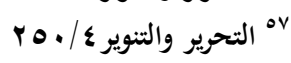

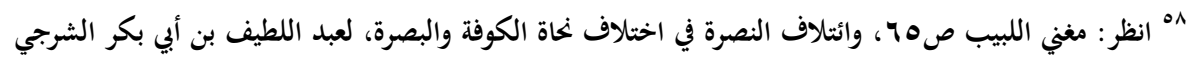

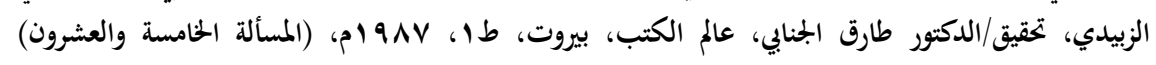

ص ص

ry

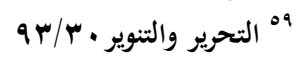

3
3

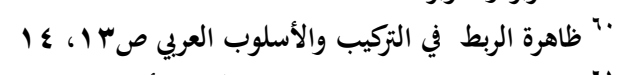

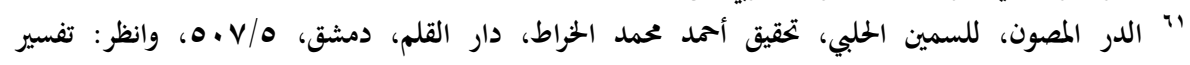

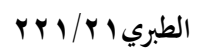

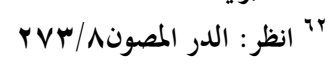

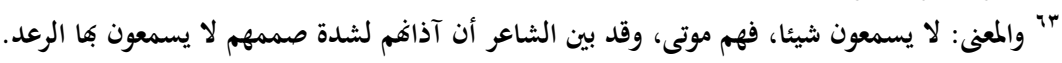

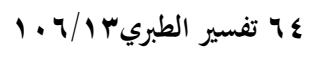

ه ا الحرر الوجيز، لابن عطية الأندلسي، تحقيق عبد السلام عبد الشافي محمد، دار الكتب العلمية، بيروت، طا،

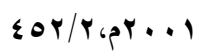

ד

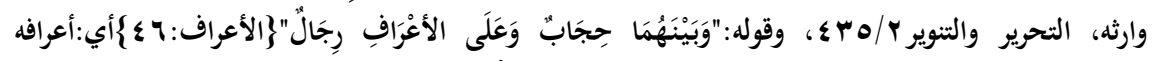

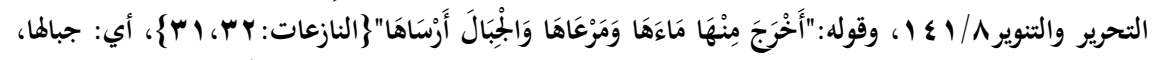

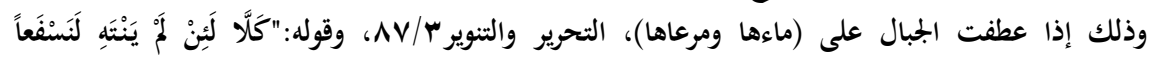

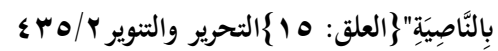

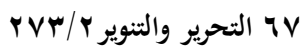

$$
\begin{aligned}
& \text { A }
\end{aligned}
$$

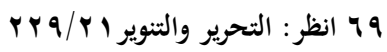


roV/rrان انظر: التحرير والتنوير V.

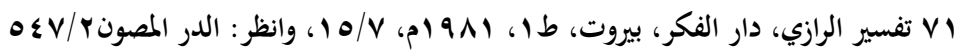

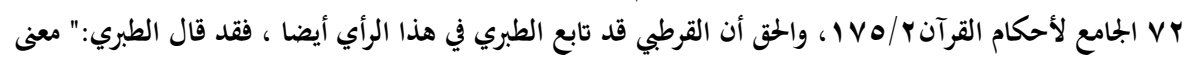

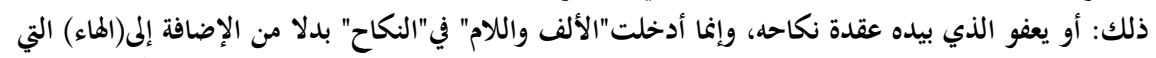

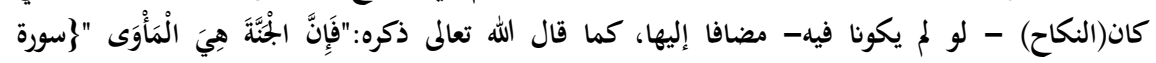

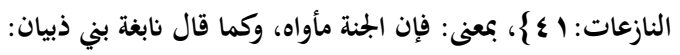

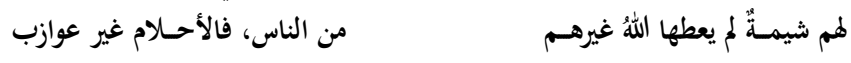

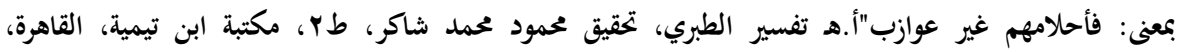

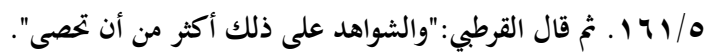

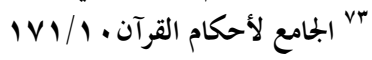

